\title{
THERMOELECTRIC MATERIALS EVALUATION PROGRAM
}

\author{
MONTHLY TOP SUMMARY REPORT \\ No. 96
}

No. MMM-2331-0423

March 15, 1976

This report has been prepared under

Contract E(11-1)-2331

with the

U.S. Energy Research and Development Administration

Prepared and Approved by:
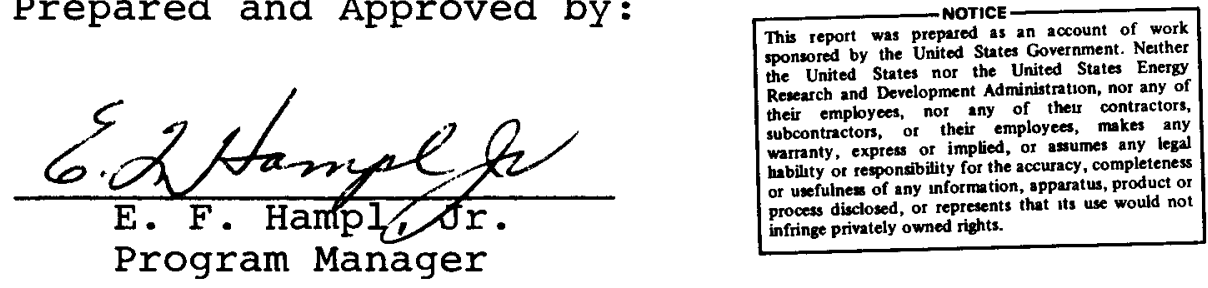

Program Manager

MINNESOTA MINING AND MANUFACTURING COMPANY

Energy Systems Project

Technical Ceramic Products Division

St. Paul, Minnesota 55101 


\section{DISCLAIMER}

This report was prepared as an account of work sponsored by an agency of the United States Government. Neither the United States Government nor any agency Thereof, nor any of their employees, makes any warranty, express or implied, or assumes any legal liability or responsibility for the accuracy, completeness, or usefulness of any information, apparatus, product, or process disclosed, or represents that its use would not infringe privately owned rights. Reference herein to any specific commercial product, process, or service by trade name, trademark, manufacturer, or otherwise does not necessarily constitute or imply its endorsement, recommendation, or favoring by the United States Government or any agency thereof. The views and opinions of authors expressed herein do not necessarily state or reflect those of the United States Government or any agency thereof. 


\section{DISCLAIMER}

Portions of this document may be illegible in electronic image products. Images are produced from the best available original document. 
Top Summary Report No. 96

Page 1

\section{INTRODUCTION}

This is the ninety-sixth Monthly Top Summary Report prepared under Contract $E(11-1)-2331$ with the United States Energy Research and Development Administration. This report, covering the performance period which extends from February 1, 1976 to February 29, 1976, has been separated into the following sections:

I. CRITICAL ACTION ITEMS

II. MAJOR MILESTONE STATUS

III. FUNDING

IV. TECHNICAL OBJECTIVES

V. PROBLEM AREAS

VI. TECHNICAL HIGHLIGHTS

I. CRITICAL ACTION ITEMS

No critical action items required attention on the part of the Contractor or ERDA during this report period.

II. MAJOR MILESTONE STATUS

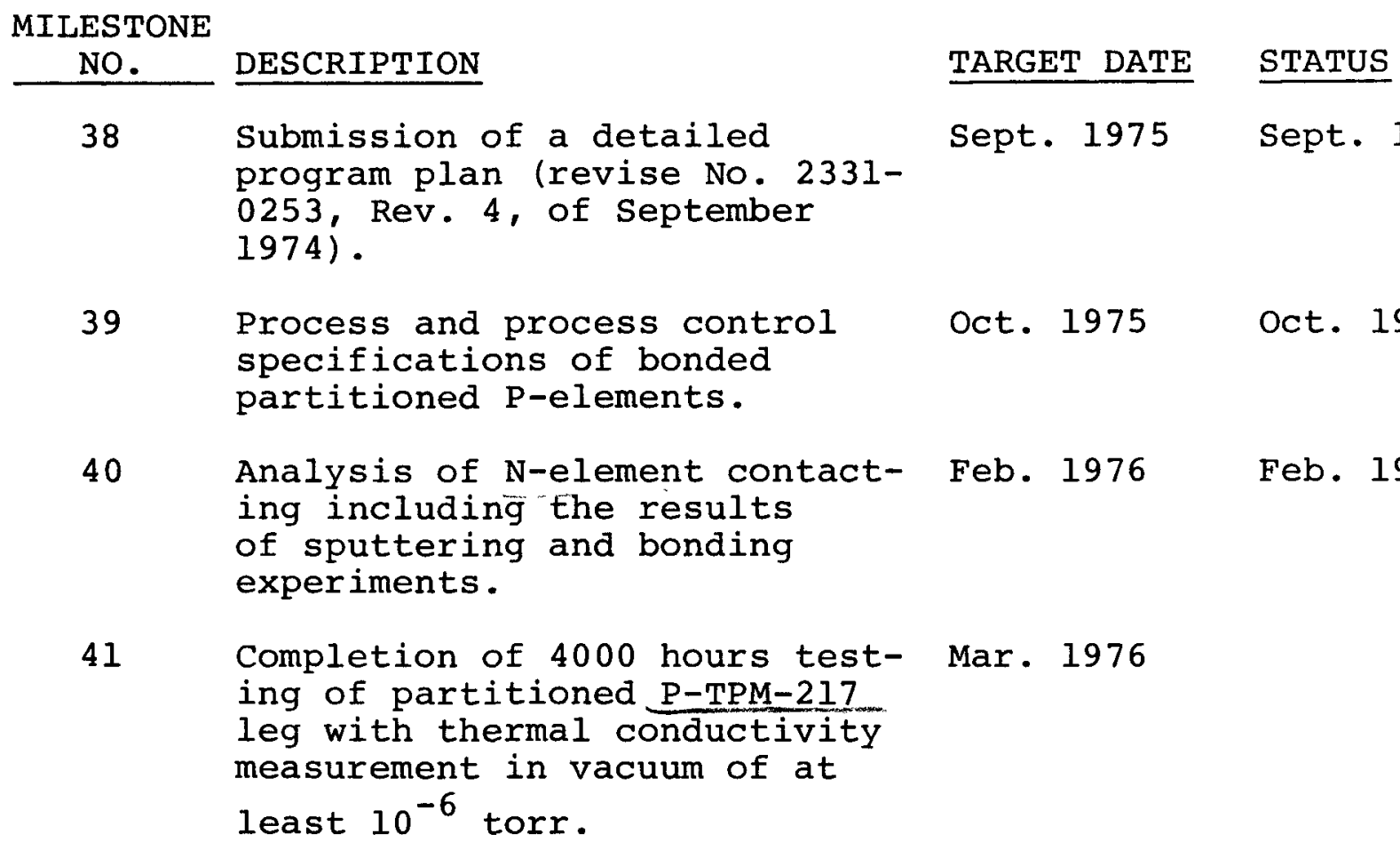

Process and process control specifications of bonded partitioned P-elements.

Analysis of $\mathrm{N}$-element contactTARGET DATE STATUS

\section{8} ing including the results of sputtering and bonding experiments.

41 Completion of 4000 hours testMar. 1976 ing of partitioned P-TPM-217 leg with thermal conductivity measurement in vacuum of at least $10^{-6}$ torr. 
Top Summary Report No. 96

Page 2

MILESTONE

NO.

DESCRIPTION

TARGET DATE

$\underline{\text { STATUS }}$

42 Preliminary process specification established for synthesis fabrication of $\mathrm{N}-$ material.

43

An improved 2-10 couple module which incorporates

April 1976 advanced in-couple hardware design will be placed on test in a configuration and physical and chemical environment appropriate to potential RTG operation in a vacuum bell jar in the temperature interval $800^{\circ} / 200^{\circ} \mathrm{C}$.

44 An improved 2-10 couple module which incorporates the advances in material development will be placed on test in a configuration and physical and chemical environment appropriate to potential RTG operation in a vacuum bell jar in the temperature interval $800^{\circ} / 200^{\circ} \mathrm{C}$.

45 A TPM-217 couple test capable

June 1976 of operating with a hot junction temperature of approximately $900^{\circ} \mathrm{C}$ will be placed on test in a bell jar.

46 An improved P-type TPM-217/ $\mathrm{N}$-gadolinium-selenide couple placed on test in a vacuum bell jar in the temperature interval of $800^{\circ} / 200^{\circ} \mathrm{C}$ to obtain a direct efficiency measurement.

47 An advanced TPM-217 module capable of producing at least 20 watts (e) placed on test at $800^{\circ} \mathrm{C}$ or higher hot junction temperature.

June 1976

July 1976

Sept. 1976 
CONZKALIOR PROGRAM MANAGER E.F.HAmpl, JY. PROTECT COST AND SCHEDULE SUMAMRY CONTRACTOR CONTRACT ADMINISTRATOR E. C. LUNd

ALO CONTRACT ALMINISTRATOR H. N. Miller
(DOLILARS IN THOUSANDS)

\section{FUNDING}

Page 3
PROJECT Thermoelectric Materials Evaluation Prog. Comrractor Minnesota Mining \& Mfg. Co.

CONTRACT E(11-1)-2331

TASK OR PHASE Total Program OR PHAsE Total Program

RERORTING NO. $\angle$ DATE $\quad$ FY'76 COST PROJECTIONS

\begin{tabular}{|l|l|l|l|l|l|l|l|l|l|l|l|l|l|} 
Feb. - 3-10-76 & JULY & AUG & SEPT. & OCT. & NOV. & DEC. & JAN. & FEB. & MAR. & APR. & MAY & JUNE & ACT.PLUS \\
\hline
\end{tabular}

Man -FORECAST \begin{tabular}{l|l|l|l|l|l|l|l|l|}
\hline -ACTUAL & 12.7 & 12.8 & 13.6 & 15.5 & 12.2 & 14.6 & 15.5 & 15.6 \\
\hline
\end{tabular}

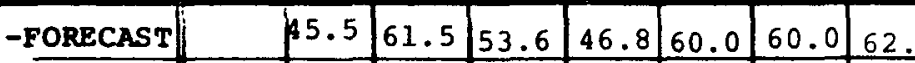

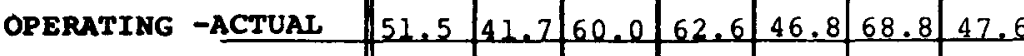

costs

\begin{tabular}{l||l|l|l|l|l|l|l|l|}
\hline ACT. CUM. & 51.5 & 93.2 & 153.2 & 215.8 & 262.6 & 331.4 & 379.0 \\
\hline
\end{tabular}

-BUD. CUM.

-BUDGET

COMM'TS OPERATING

-EQUIPMENT

IEGEND REPORT $\$(000)$ MILESTONE STATUS AND FY'76 CUMULATIVE OPERATING COSTS

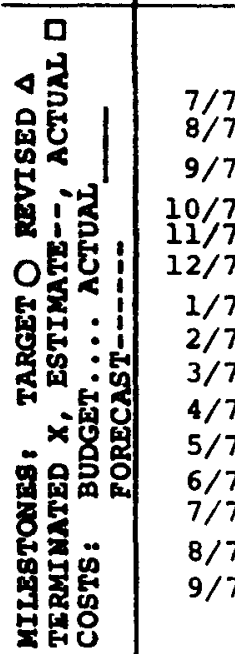

Paros orat

\section{$37 \quad 38 \quad 39$}

\begin{tabular}{|l|c|r|r|}
\hline \multicolumn{4}{|c|}{ FY 76 COST DETAIL } \\
\hline & MONTH & $\begin{array}{c}\text { CUMU- } \\
\text { TATIVE }\end{array}$ & BUDGET \\
\hline DIR.SALARIES & 21.4 & 137.0 & \\
\hline OVERHEAD & 15.3 & 88.4 & \\
\hline MATERIAL & 4.6 & 102.7 & \\
\hline FEE & 3.2 & 26.4 & \\
\hline OTHER & 3.1 & 24.5 & \\
\hline & & & \\
\hline & & & \\
\hline TOT.OPERATNG & 47.6 & 379.0 & \\
\hline EQUIPMENT & 0 & 63.7 & \\
\hline
\end{tabular}

JULY AUG. SEPT. OCT. NOV PEC. JAN/ GPR/ TUR.

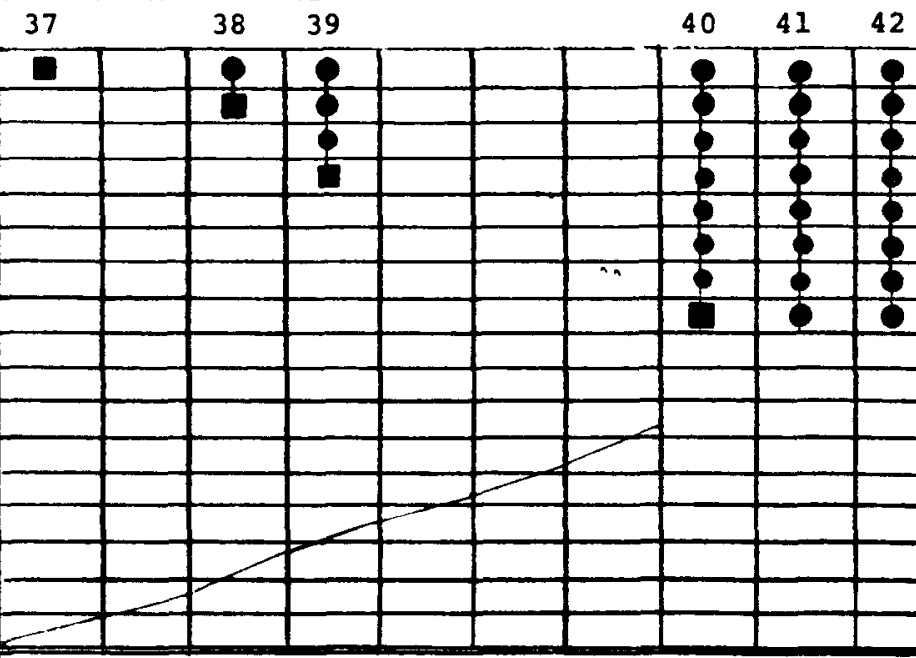

PROJECT CUMULATIVE OPERATING COSTS 47

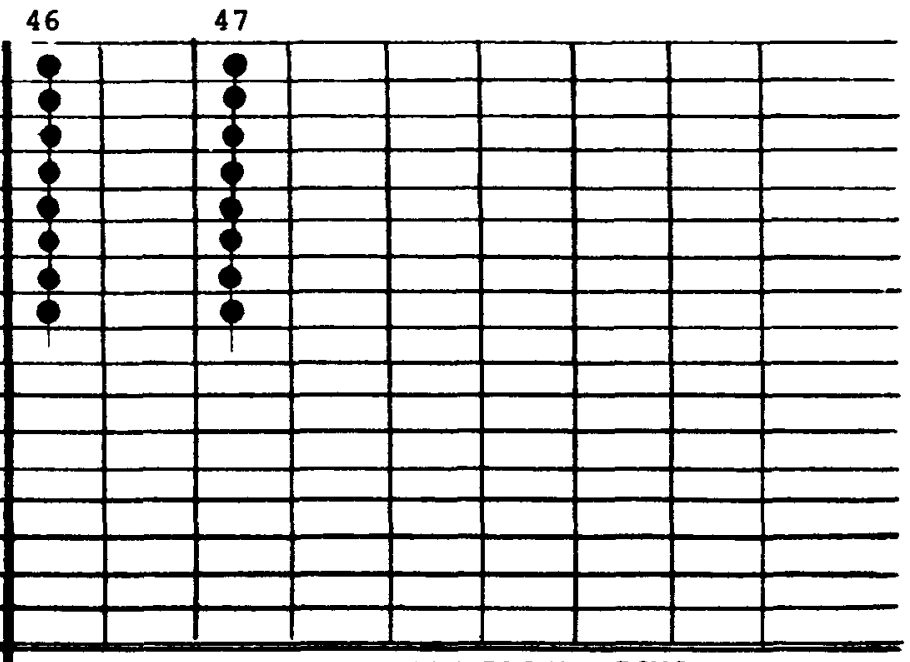
OPERATING COST PROJECTIONS 
Top Summary Report No. 96

Page 4

\section{TECHNICAL OBJECTIVES AND PROGRAM HIGHLIGHTS}

TASK 1.0: The objective of this task is to optimize an N-type thermoelectric material, gadolinium-selenide, to match the thermoelectric properties of and be compatible with P-type TPM-217 thermoelectric material.

TASK 2.0: The objective of this task is to experimentally describe the chemical, electrical, and physical behavior and to measure long-term performance of P-type TPM-217 at temperatures to $1000^{\circ} \mathrm{C}$.

TASK 3.0: The objectives of this task are to design, obtain data, demonstrate performance, and predict long-term performance of thermoelectric couples using TPM-217 as the P-material.

TASK 4.0: The objective of this task is to develop a preliminary design for a TPM-2I7 couple.

TASK 5.0: The objective of this task is to provide liaison and limited amounts of TPM-217 thermoelectric material to the Jet Propulsion Laboratory of the California Institute of Technology.

TASK 6.0: The objective of this task is to provide liaison and limited amounts of TPM-217 thermoelectric material to the Gulf Atomic Company.

TASK 7.0: The objective of this task is to provide, at the request of the ERDA Project Director, technical evaluation of new thermoelectric materials or new thermoelectric module technology of potential use to ERDA/DANES.

TASK 8.0: The objective of this task is to evaluate and develop advanced energy conversion and heat supply concepts which will take advantage of the unique properties of TPM-217 materials.

\section{PROBLEM AREAS}

No potential problems from a technical viewpoint were encountered during this report period. 
Top Summary Report No. 96

Page 5

VI. TECHNICAL HIGHLIGHTS

Task 1.0 - N-Type Material Development

1.2 MATERIAL SYNTHESIS

Gadolinium-selenide compositions were synthesized and cast into geometries suitable for electrical ( $S$ and $\rho$ ) characterization. The synthesis samples are related to process experiments which are in progress and have the following objectives:

- Control Seebeck coefficient by precisely controlling the ratio of chalcogenide to rare earth.

- Control formation of second-phase material on grain boundary.

Periodic processing of large batches of $\mathrm{N}$-type material continues in order to provide sufficient material for processing studies and module development. Batches BB-1 through BB-23 have been pressed and sintered to provide material for module testing, mechanical testing, and contacting studies. Batch BB-10 was used in pressing/sintering experiment No. 6 described in Top Summary Report No. 84. Batches BB-11 through BB-14 were pressed and sintered according to procedures described in Top summary Report No. 86. Batches $\mathrm{BB}-14$ through $\mathrm{BB}-23$ were prepared for use in the 20-watt module; these batches were pressed and sintered by the same procedure (described in Top Summary Report No. 86 for BB-14). Batch BB-24 was used for $R F$ induction casting experiments. Batch BB-25 was used in pressing/sintering experiments. Batch BB-26 was aborted when the furnace thermocouple malfunctioned during the $220^{\circ} \mathrm{C}$ soak. Batches $\mathrm{BB}-27, \mathrm{BB}-28, \mathrm{BB}-29, \mathrm{BB}-30, \mathrm{BB}-34$, and $B B-35$ have completed the RQC cycle and have been used in pressing/ sintering experiments. Batches $\mathrm{BB}-31, \mathrm{BB}-33$, and $\mathrm{BB}-36$ have completed the RQC cycle and will be held in inventory in the RQC form until needed. Batches $\mathrm{BB}-37, \mathrm{BB}-38, \mathrm{BB}-40, \mathrm{BB}-41, \mathrm{BB}-42$, and BB-43 have completed the LTR cycle and currently await the RQC casting cycle. Batches $\mathrm{BB}-32$ and $\mathrm{BB}-39$ were aborted during the LTR due to an improper seal of the quartz tube. Batches $B B-30$, $\mathrm{BB}-32, \mathrm{BB}-34, \mathrm{BB}-35, \mathrm{BB}-38, \mathrm{BB}-39, \mathrm{BB}-40, \mathrm{BB}-41, \mathrm{BB}-42$, and $\mathrm{BB}-43$ have been synthesized with the nominal composition GdSe $_{1.480}$ whereas other batches have been synthesized with the standard $\mathrm{GdSe}_{1.492}$ composition. It should be noted that batches BB-31, $\mathrm{BB}-34$, and $\mathrm{BB}-35$ appeared to have incomplete reaction in the LTR. There were two or three small hard pellets in each sample which are not usually found in the rather powdery normal LTR reaction. However, the samples were rapid quench cast with the small pellets so as not to alter the composition of the batch. In addition, batch $\mathrm{BB}-35$ was rapid quench cast a second time at 
Top Summary Report No. 96

Page 6

a higher temperature and for an extended time in an attempt to improve the homogenization of the batch. The weight loss data of all BB batches processed to date are summarized in Table I.

High temperature processing of samples $\mathrm{N}-2515$ through $\mathrm{N}-2518$ has begun. This series, prepared from Ames $12773 \mathrm{MSl}$ gadolinium metal, was designed to evaluate the effects of the preparation of the pure gadolinium metal in tungsten crucibles. The compositional data for this series are shown in Table II.

TABLE II

Weight Loss Data - Samples N-2515 through N-2518

"N" No.

2515

2516

2517

2518

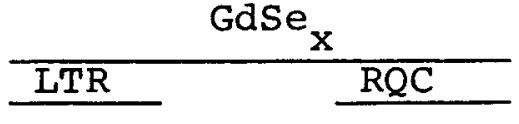

1.4922

1.4918

1.4918

1.4922

High temperature processing of the erbium, neodymium, and samarium doping series (samples $\mathrm{N}-2466$ through $\mathrm{N}-2471$, and samples $\mathrm{N}-2487$ through $\mathrm{N}-2492$ ) is complete with the exception of the casting of N-2492. All available data on these samples was tabulated in Top Summary Report No. 92 .

\subsection{MATERIAL ANALYSES}

1.3.1 Chemical, Crystal structure, and Metallurgical Analyses

Chemical analyses are being performed on raw materials, on atmosphere for control of the synthesis process, on element contact structure, on doping studies, and on isothermal chemical compatibility experiments as required.

\subsubsection{Thermoelectric Properties}

Sixteen samples of $\mathrm{N}$ - and $\mathrm{P}$-materials were measured for Seebeck coefficient and electrical resistivity on a routine basis. The hardware and software for the new seebeck measurement apparatus is being checked out and calibrated as time permits. 
Top Summary Report No. 96

Page 7

TABLE I

Compositional Data for 65-Gram N-Type Batches

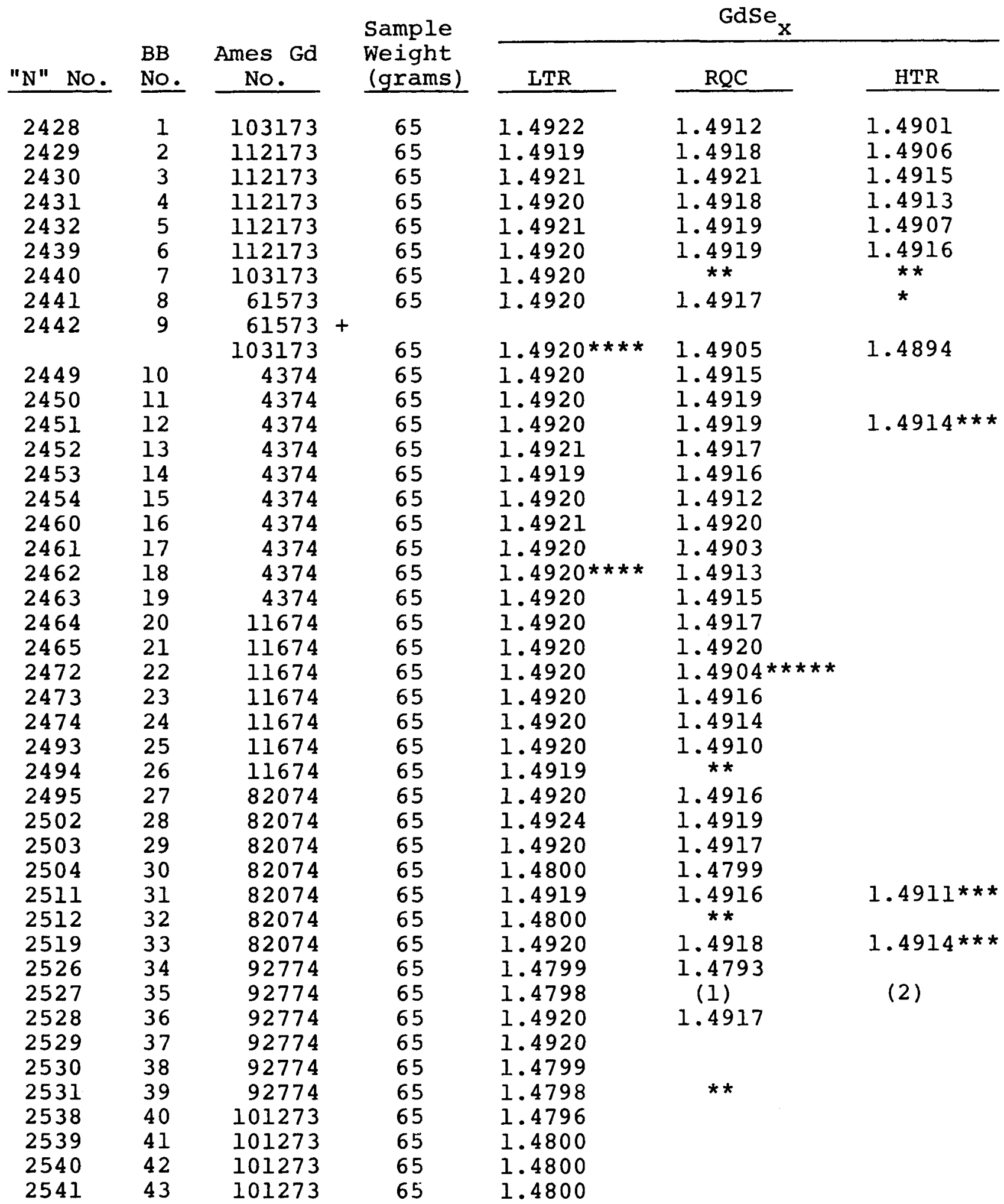


Top Summary Report No. 96

Page 8

TABLE I (Continued)

*Casting crucible broke so accurate weight of cast ingot could not be obtained.

**Sample did not survive the LTR cycle.

$* * *$ Composition of $\mathrm{RQC}$ No. 2 .

****Vitreous carbon LTR crucible broke during LTR cycle.

$\star * \star * *$ Composition may be inaccurate due to a piece of material adhering to the casting crucible.

(1) Sample apparently gained weight during RQC (may have been a weighing error). Therefore, RQC composition cannot be calculated.

(2) RQC No. 2 - Sample again appeared to gain weight. Due to this weight gain and the fact that the RQC No. 1 composition could not be calculated, no RQC composition was calculated. 
Top Summary Report No. 96

Page 9

1. 4 MATERIAL PROCESSING

1.4.1 Pressing and sintering studies

Pressing and Sintering Experiments:

Cold pressing/sintering studies continue with the objective of forming high density, mechanically strong thermoelectric leg structures while at the same time reducing extraneous resistance to form elements with electrical properties on or near the $10 \%$ current standard material trend line. Elements have been formed with approximately a $30 \%$ extraneous resistance value.

The major variables studied in this pressing/sintering program include:

- Material used - HTR and RQC reacted ingot material

- Particle size - from $45 \mu$ to $5 \mu$ and mixtures thereof

- Element geometry - 0.188" - 0.500" diameter

- Pressing pressure - related to geometry - 2,000 to 68,000 psi

- Atmosphere control:

1. LabVac box: "as is" to implementing the USERDA Ames gas purification system.

2. Transporting green pressed legs from the LabVac to the Astro Furnace.

3. Astro furnace atmosphere: "as is" to use of gas purifier.

- Sintering Cycle

1. Heat-up rate

2. Soak temperature

3. Soak time

- Particle reduction techniques

- Homogeneity of starting materials

- Purified kerosene "wet"/air grinding

- Effects of lubricants

- Hot pressing 
Top Summary Report No. 96

Page 10

The objective of cold pressing/sintering experiment $45, \mathrm{BB}-28$ $\left(65-\right.$ gram RQC, composition $\left.\mathrm{GdSe}_{1.4919}\right)$ was to investigate the effect of wet grinding, sieving and pressing on $\mathrm{N}$-leg electrical properties and physical structure. The liquid used for wet grinding was benzene purified by passing through an alumina column and subsequently stored with molecular sieve to remove water. A total of almost forty milliliters of benzene was added to the 65-gram batch. The helium atmosphere in the glove box was passed through the molecular sieve section of the purifier because the getter furnace is still under repair. This atmosphere was of sufficient purity to allow a bare tungsten filament to burn for approximately three hours; with the getter furnace working properly, the tungsten filament would last over 1000 hours. The grinding sequence was the same as other recent experiments (e.g. P/S 42), but grinding times were reduced. The slurry did not stick to the walls or grinding balls and a very uniform, rapid particle reduction was observed. The slurry was placed on the No. 20 mesh sieve, dried out very rapidly, and the dry powder was completely worked through the sieves in much less time than normal material. Half the powder was prepressed and dry pressed with octoil lubrication, while the other half was mixed with more benzene and "wet pressed" without the Octoil lubricant. All legs were simultaneoulsy sintered at $1650^{\circ} \mathrm{C}$. The grinding, pressing, and sintering cycle is summarized in Table III.

The metallographic results show some promise for "wet grinding." Grain size was smaller and more uniform than most dry grinding experiments. Legs pressed dry with Octoil ram lubrication after wet grinding showed varying grain growth regions and higher porosity than legs wet pressed with no Octoil. Pores were of $7 \mu \mathrm{m}$ diameter and located on grain boundaries for the wet pressed structure; dry pressed pores were 13 to $20 \mu \mathrm{m}$ and larger on and within grain boundaries.

\section{Equipment :}

\section{Glove Box - Inert Gas Purification System:}

The purifier remains under repair after it was found that a hole had been melted in the side of the furnace tube. Other parts had been repaired; the hole, however, was concealed by the furnace tube windings on a ceramic form, resulting in additional delays. Three months is the estimate to obtain a replacement Inconel tube; consequently, an Inconel patch was made and welded into the area cut out of the tube. The purifier is now ready for final reassembly and leak checking.

The cost estimate of a new purifier system is being made as Bernie Beaudry, ERDA Ames Laboratory, has recently indicated the desire to recall the loaned Ames system about February 1977. 
Top Summary Report No. 96

Page 11

TABLE III

Pressing/Sintering experiments Performed February 1976

\begin{tabular}{|c|c|c|c|c|c|c|c|c|c|c|c|c|c|}
\hline $\begin{array}{l}\text { P/S Exp. } \\
\text { No. }\end{array}$ & Batch & wt. & $\begin{array}{c}\mathrm{RQC} \\
\mathrm{GdSe}_{\mathrm{X}} \mathrm{x}\end{array}$ & $\mathrm{Gr}$ & $\frac{\text { inding }}{2}$ & $\frac{\text { Sequence }}{3}$ & 4 & $\begin{array}{l}\text { Sintering } \\
\text { Temp }\left({ }^{\circ} \mathrm{C}\right)\end{array}$ & $\begin{array}{l}\text { Grain } \\
\text { Size } \\
(\mu \mathrm{m})\end{array}$ & $\begin{array}{l}\text { Prepress } \\
\text { Pressure } \\
\text { (psig) }\end{array}$ & $\begin{array}{l}\text { Pressing } \\
\text { Pressure } \\
\text { (psig) }\end{array}$ & $\begin{array}{l}\text { Density } \\
(g / c c)\end{array}$ & $\begin{array}{l}P_{\mathrm{RT}} \\
(\mathrm{m} \Omega-\mathrm{cm})\end{array}$ \\
\hline 45 & $\mathrm{BB}-28$ & 65 & 1.4919 & $\begin{array}{l}1 / 4 \mathrm{R} \\
5 \mathrm{~min}\end{array}$ & $\begin{array}{l}1 / 2 \mathrm{~L} \\
5 \mathrm{~min}\end{array}$ & $\begin{array}{l}3 / 4 \mathrm{R} \\
\text { and L } \\
10 \mathrm{~min}\end{array}$ & $\begin{array}{l}1 / 2 \mathrm{R} \\
\text { and } \mathrm{L}^{\star} \\
5 \mathrm{~min}\end{array}$ & $\begin{array}{l}1650 \\
1650 \\
1650\end{array}$ & $\begin{array}{c}10 \\
13-65 \\
7\end{array}$ & $\begin{array}{l}-\overline{200} \\
200\end{array}$ & $\begin{array}{l}8800 \\
8800 \\
8800\end{array}$ & $\begin{array}{l}6.72 \\
7.19 \\
6.15\end{array}$ & $\begin{array}{l}4.9 * * \\
5.5 * * * \\
9.4\end{array}$ \\
\hline
\end{tabular}

*Wet grinding using benzene for entire sequence.

**This element "wet" pressed - no Octoil lubrication of pressing rams as was done for other two listed.

***Lateral crack running through center - found during metallographic examination. 
Top Summary Report No. 96

Page 12

\subsection{ELEMENT CONTACTING}

A report, "Analysis of $\mathrm{N}$-Gadolinium-Selenide Element Contacting," is being prepared to satisfy the requirements of milestone No. 40 .

\subsection{INGRADIENT COMPATIBILITY AND LIFE TESTING}

An updated summary of $\mathrm{N}$-leg performance for the last eight months is contained in Table IV. Theoretical values for current standard elements are shown in the chart for reference. The duration of each of the tests at the end of February is also shown in this table.

The six-station N-leg tests (ATT 322, 324, 325, 365, 366, 367) have now been terminated. A post-test analysis of the N-legs will be performed and the results will be reported in subsequent monthly reports.

A new series of $\mathrm{N}$-leg tests (ATT 407-412) has been initiated in the the six-station fixture which previously contained tests ATT 322 et al. The two objectives of these tests are:

1. to life test legs at 508 nominal extraneous resistance,

2. to determine the effect of hot end contacting means on performance.

Three different hot end contacting configurations were used with two tests of each type; the element test configuration is summarized in Table $\mathrm{V}$. The tests are operating in a nominal temperature interval of $850^{\circ} / 200^{\circ} \mathrm{C}$ in a vacuum of $2.5 \times 10^{-7}$ torr and the legs are uninsulated.

TABLE V

Element Configuration of Hot End Contacting N-Leg Series

\begin{tabular}{ccc} 
ATT No. & Hot End Foil & Sputter Con \\
\cline { 2 - 3 } 407 & Gd & W \\
408 & Gd & W \\
409 & Pt & W \\
410 & Pt & W \\
411 & None & Cu \\
412 & None & Cu
\end{tabular}

Additional N-legs which are currently on test are ATT 364, 378, and 385. ATT 364 was initiated in April 1975 to determine the status of the $\mathrm{N}$-material and contacting procedures at that time. The test has been running continuously since that time with the exception of one cool-down due to a light bulb/heater failure. 
Key to Parenthetical Numbers TABLE IV. Eight-Month Life Test Performance Summarv

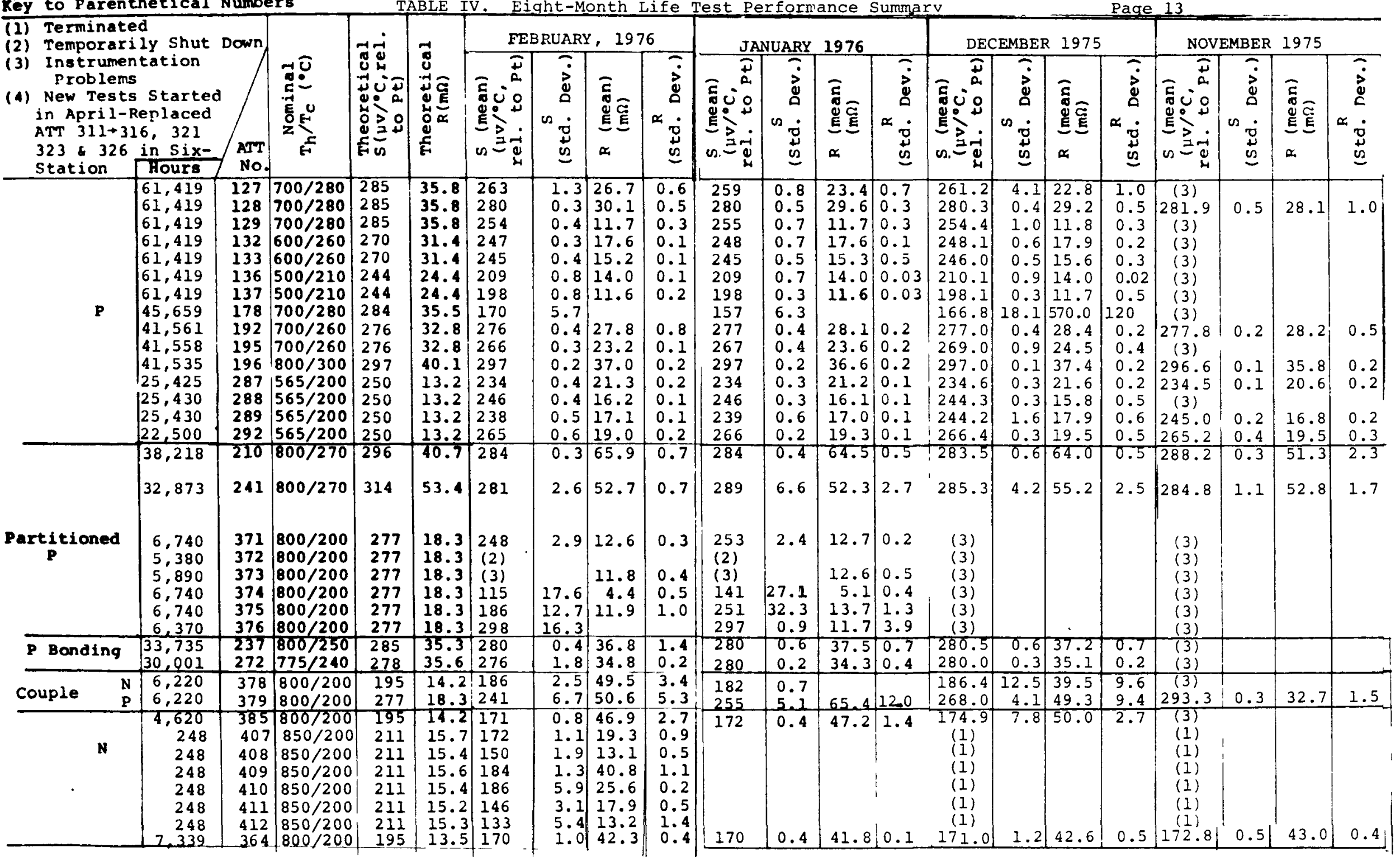


Key to Parenthetical Numbers

(1) Terminated

(2) Temporarily Shut Down Problems

(4) New Tests Started

in April-Renlaced

in April-Renlaced
ATT $311+316,321$
323 in 326 in 1 - ATT

323 in S1x- ATT

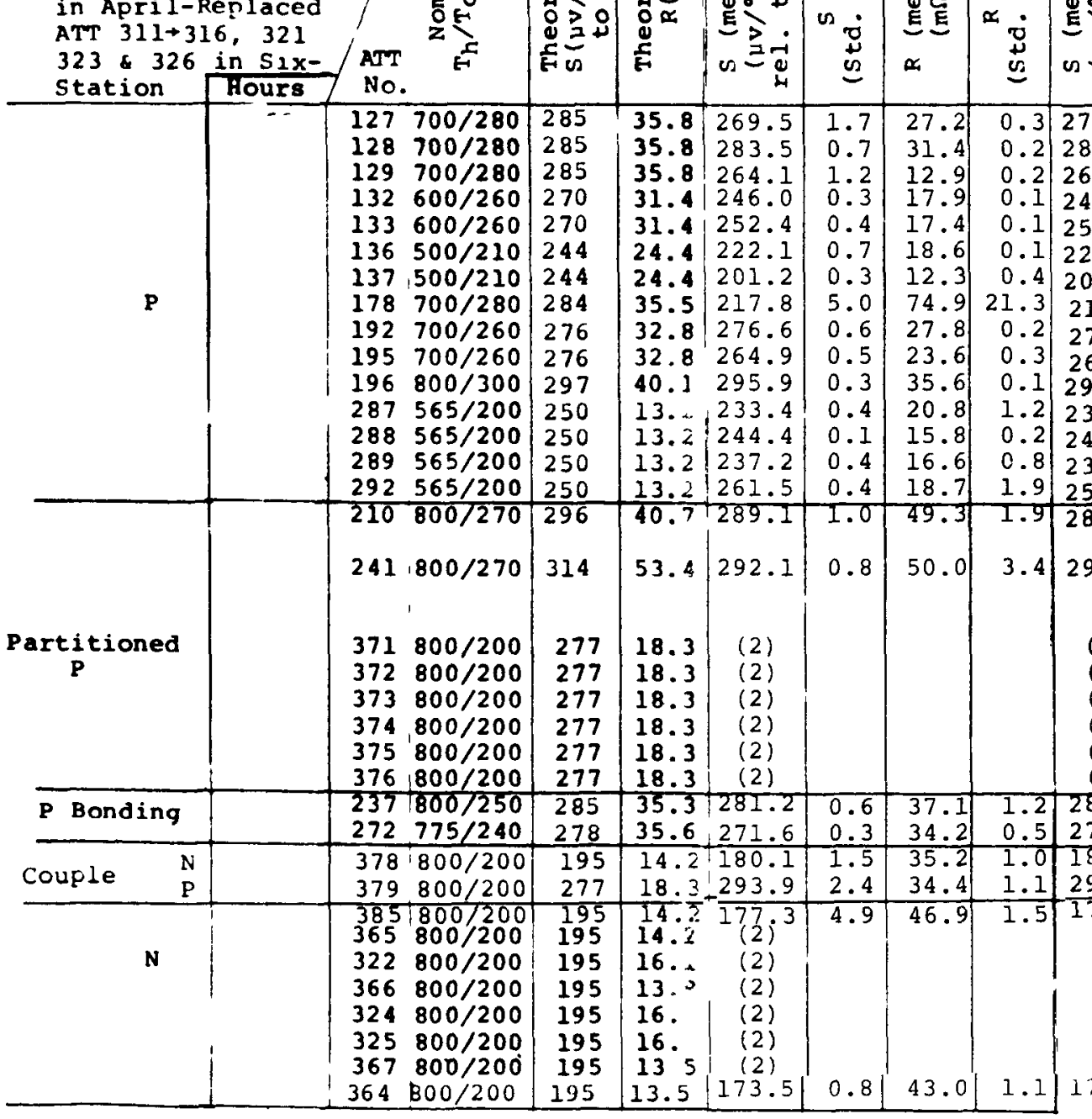

ABLE IV (continues)

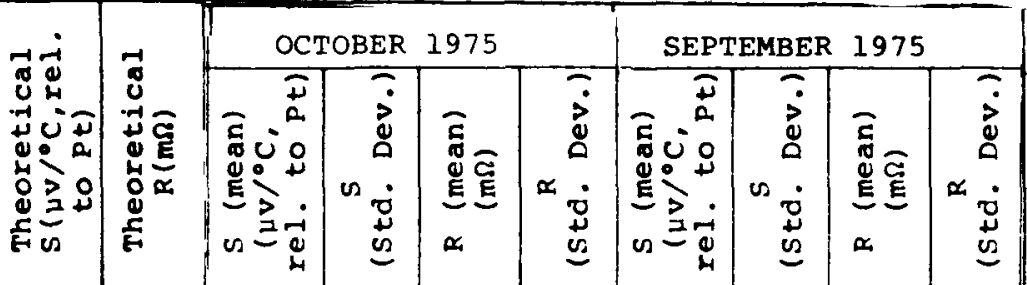

Page 14

\begin{tabular}{|c|c|c|c|c|c|c|c|}
\hline \multicolumn{4}{|c|}{ AUGUST 1975} & \multicolumn{4}{|c|}{ JULY 1975} \\
\hline 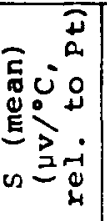 & 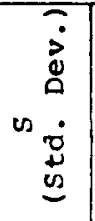 & 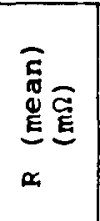 & 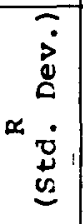 & 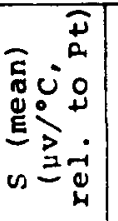 & 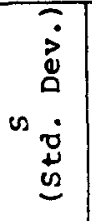 & 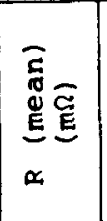 & 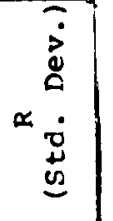 \\
\hline $\begin{array}{l}268.2 \\
287.7 \\
264.4 \\
248.2 \\
251.9 \\
218.4 \\
200.3 \\
192.5 \\
276.3 \\
266.2 \\
295.2 \\
232.0 \\
245.6 \\
242.2 \\
231.3 \\
325.3\end{array}$ & \begin{tabular}{l|}
1.1 \\
0.5 \\
1.0 \\
0.3 \\
0.5 \\
1.0 \\
0.4 \\
4.2 \\
0.5 \\
0.5 \\
0.3 \\
0.3 \\
3.2 \\
0.3 \\
0.6 \\
1
\end{tabular} & $\begin{array}{l}25.0 \\
29.3 \\
13.0 \\
18.3 \\
17.5 \\
17.7 \\
12.2 \\
52.6 \\
25.7 \\
24.0 \\
36.6 \\
20.6 \\
16.5 \\
17.1 \\
13.3 \\
50\end{array}$ & $\begin{array}{l}1.1 \\
0.5 \\
0.2 \\
0.4 \\
1.0 \\
0.6 \\
0.1 \\
2.6 \\
0.5 \\
0.2 \\
0.2 \\
1.0 \\
0.5 \\
0.9 \\
0.4 \\
3\end{array}$ & \begin{tabular}{l|}
266.8 \\
280.8 \\
262.6 \\
248.3 \\
251.3 \\
217.7 \\
196.6 \\
192.7 \\
276.0 \\
267.2 \\
294.9 \\
231.4 \\
244.4 \\
241.3 \\
229.2 \\
205
\end{tabular} & \begin{tabular}{l|}
0.8 \\
3.6 \\
1.3 \\
0.3 \\
0.4 \\
0.9 \\
2.2 \\
2.7 \\
0.5 \\
0.7 \\
0.7 \\
0.5 \\
0.3 \\
0.6 \\
2.2 \\
2
\end{tabular} & \begin{tabular}{|l|}
22.8 \\
38.8 \\
12.8 \\
18.4 \\
17.5 \\
17.5 \\
11.6 \\
48.4 \\
27.0 \\
24.7 \\
37.0 \\
20.2 \\
16.3 \\
17.9 \\
12.9 \\
5
\end{tabular} & \begin{tabular}{|r|}
0.7 \\
5.97 \\
0.3 \\
0.0 \\
0.1 \\
0.1 \\
0.4 \\
2.3 \\
0.7 \\
0.3 \\
0.2 \\
0.2 \\
0.6 \\
0.7 \\
0.9 \\
3
\end{tabular} \\
\hline 285.3 & 1.7 & 59.1 & 3.1 & 286.8 & 3.0 & 51.8 & \\
\hline 281.7 & 5.2 & 46.1 & 2.0 & 292.9 & 1.5 & 43.5 & 1.5 \\
\hline $\begin{array}{l}253.8 \\
256.0 \\
(3) \\
233.0 \\
233.3 \\
(2)\end{array}$ & $\begin{array}{r}5.4 \\
1.0 \\
14.1 \\
3.6\end{array}$ & $\begin{array}{l}12.5 \\
21.0 \\
17.6 \\
12.9 \\
14.1 \\
(2)\end{array}$ & $\begin{array}{l}0.5 \\
2.0 \\
0.6 \\
0.9 \\
0.4\end{array}$ & $\begin{array}{c}257.0 \\
254.1 \\
(3) \\
255.3 \\
241.9 \\
293.8 \\
\end{array}$ & $\begin{array}{l}3.4 \\
3.1 \\
3.9 \\
8.7 \\
2.5 \\
\end{array}$ & $\begin{array}{l}12.7 \\
18.5 \\
20.3 \\
14.3 \\
16.4 \\
13)^{2}\end{array}$ & $\begin{array}{l}0.3 \\
2.3 \\
1.3 \\
0.3 \\
1.5\end{array}$ \\
\hline $\begin{array}{l}279.6 \\
268.9\end{array}$ & $\begin{array}{l}0.6 \\
0.3\end{array}$ & $\begin{array}{l}37.7 \\
33.5\end{array}$ & $\begin{array}{l}0.3 \\
0.2\end{array}$ & $\begin{array}{l}279.6 \\
269.0\end{array}$ & $\begin{array}{l}0.6 \\
0.3\end{array}$ & $\begin{array}{l}37.1 \\
33.2\end{array}$ & $\begin{array}{l}0.9 \\
0.1\end{array}$ \\
\hline $\begin{array}{l}187.2 \\
295.3\end{array}$ & 1.4 & $\begin{array}{l}32.8 \\
33.3\end{array}$ & 0.7 & $\begin{array}{l}190.9 \\
293.5\end{array}$ & $\begin{array}{l}1.3 \\
1.6\end{array}$ & $\begin{array}{l}35.7 \\
33.4\end{array}$ & $\begin{array}{l}1.0 \\
2.2\end{array}$ \\
\hline $\begin{array}{l}177.7 \\
216.2 \\
220.7 \\
210.0 \\
(3)\end{array}$ & $\mid \begin{array}{r}2.4 \\
2.4 \\
34.4 \\
0.4\end{array}$ & $\begin{array}{r}19.5 \\
90.1 \\
191.2 \\
42.0 \\
(3)\end{array}$ & $\begin{array}{r}1.0 \\
1.0 \\
2.9 \\
0.6\end{array}$ & $\begin{array}{c}186.9 \\
224.8 \\
200.0 \\
206.8 \\
(3)\end{array}$ & \begin{tabular}{|l}
5.7 \\
2.4 \\
4.3 \\
1.8
\end{tabular} & $\begin{array}{l}28.1 \\
95.9 \\
262.4 \\
36.8 \\
(3)\end{array}$ & $\begin{array}{r}4.6 \\
1.0 \\
20.7 \\
1.9\end{array}$ \\
\hline $\begin{array}{l}219.5 \\
192.4 \\
176.1\end{array}$ & $\begin{array}{r}0.7 \\
0.3 \\
1.5\end{array}$ & $\mid \begin{array}{c}156.3 \\
50.9 \\
38.9\end{array}$ & $\begin{array}{l}0.9 \\
0.6 \\
0.7\end{array}$ & $\begin{array}{r}218.3 \\
193.5 \\
178.2\end{array}$ & $\left.\right|_{0.6} ^{1.9} 0$ & $\begin{array}{c}151.4 \\
53.9 \\
40.5\end{array}$ & $\begin{array}{r}3.5 \\
1.0 \\
0.5 \\
\end{array}$ \\
\hline
\end{tabular}


Top Summary Report No. 96

Page 15

It has accumulated 7300 hours test time and the performance has been quite stable in recent months. The light bulb/heater failure occurred in June. The resistance increased from approximately 28 to 42 mohms at that time, indicating some cracking. The best performance of this element was achieved in May 1975; this performance was characteristic of $110 \%$ extraneous resistance on the $\mathrm{N}-$ leg. Thus, this element is not representative of the type of elements which are currently being produced.

Tests ATT 378 and 385 both experienced thermal cycles due to light bulb/heater replacement this month. The resistances did not significantly increase as a result of these cycles. Both of these tests have experienced numerous thermal cycles; thus, the possibility of terminating these tests in the neat furture will be evaluated. 
Top Summary Report No. 96

Page 16

Task 2.0 - TPM-217 P-Type Characterization

\section{2 and 2.3 MATERIAL PREPARATION AND ANALYSIS}

The casting of P-type TPM- 217 batch R-28 has been completed and the characterization data of the batch is reported in Table VI.

\subsection{ELEMENT CONTACTING}

Quality Control Apparatus:

The second quality control test fixture (Top Summary Report No. 95, page 19) is now in routine operation. This additional fixture increases the present electrical QC measurement capability to approximately twenty elements per week.

\subsection{THERMODYNAMIC STABILITY}

The series of sealed tube free-evaporation experiments, described in Top Summary Report No. 85, continues. This work was initiated to supplement the mass spectrometer vapor pressure determinations. The importance of this type of experiment lies in the fact that the rate of material loss in an operating generator approximates a Langmuir free evaporation process rather than a Knudsen cell equilibrium process. The principal results obtained in recent months were summarized in Top Summary Report No. 90, page 23, and the experimental arrangement was described in Top Summary Report No. 85. As reported in Top Summary Report Nos. 93 and 94 , a test facility consisting of an ion pumped quartz sample tube connected to a partial pressure analyzer has been constructed. The partial pressure analyzer has shown extensive desorption of gasses from the quartz tube and sample; the principle gaseous species identified in the sample tube are $\mathrm{H}_{2} \mathrm{O}, \mathrm{H}_{2}, \mathrm{CO}, \mathrm{CO}_{2}, \mathrm{~N}_{2}$, and hydrocarbon fragments. After repair of leaks which occurred in the initial configurations, the system has proven capable of operation at $3 \times 10^{-8}$ torr after initial outgassing.

Experiments were performed this month using this system with the addition of copper, molybdenum, or titanium getter tubes around the samples to reduce the selenium diffusion length. The sample weight loss rates, $R_{m}$, measured with these getter tubes were $6 \times 10^{-7}, 2.3 \times 10^{-7^{m}}$, and $3.0 \times 10^{-7}$ for the copper, molybdenum, and titanium getters, respectively. A selenium deposit formed on the quartz tube when the copper and molybdenum getters were used, but did not form when the titanium getter was used. In addition, the weight gain of the titanium was greater than for the copper or molybdenum tubes. This indicates that titanium is effective in gettering the selenium and reducing its diffusion length. 
Top Summary Report No. 96

Page 17

TABLE VI

Characterization Data - R-28

Sample

Atomic Absorption Emission Spectrographic* Analysis - owt Ag

Analysis (ppm by weight)

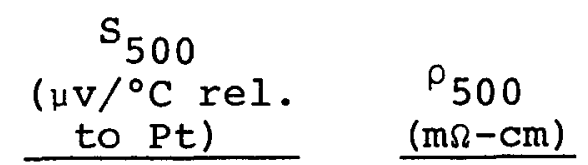

Fe $\quad \underline{M g}$

$\begin{array}{ll}\text { Synthesis Top } \\ \text { Synthesis } & \text { Bottom } \\ \text { Tier } 1 & \text { No. } 2 \\ \text { Tier } 3 & \text { No. } 1 \\ \text { Tier } 4 / 5 & \text { No. } 2 \\ \text { Tier } 8 & \text { No. } 1 \\ \text { Tier } 10 & \text { No. } 2 \\ \text { Tier } 1 & \text { No. } 1 \\ \text { Tier } 4 / 5 & \text { No. } 1 \\ \text { Tier } 10 & \text { No. } 1\end{array}$

1.53)

1.55) mean

$1.56) \quad 1.54$

$1.54)$

$1.54)$

$\begin{aligned} 1 & <1 \\ 11 & <1 \\ 1 & <1 \\ 1 & <1 \\ 1 & <1 \\ <1 & <1 \\ 1 & <1\end{aligned}$

*These were the only elements detected.

$$
\begin{aligned}
& \text { +258) mean } \\
& +259)+260.0 \\
& +263 \text { ) }
\end{aligned}
$$


Top Summary Report No. 96

Page 18

As reported in Top Summary Report No. 95, a series of weight loss experiments in sealed tubes with known pressures of argon has been conducted. The measured weight loss data $\left(R_{m}\right)$, is given in Figure 1 and Table VII. The objective of this experiment was to determine the correlation of weight loss rate with inert gas pressure, so no attempt was made to correct this measured data for tube geometry or convection effects. The line in Figure 1 , corresponding to a simple inverse relation between weight loss rate and inert gas pressure, is seen to be a good representation of the experimental data in the region 0.1 torr to 2.5 torr. It is concluded that the sublimation rate of selenium from TPM- 217 can be significantly reduced by inert gas pressure. Further experiments are being performed to obtain additional data on the effects of pressure on weight loss rate in different geometries but, due to the low loss rates, no further data was obtained this month.

TABLE VII

Summary of Vapor Pressure Data

\begin{tabular}{|c|c|c|c|c|c|}
\hline Sample & Material & $\begin{array}{l}\text { Temp. } \\
\left({ }^{\circ} \mathrm{C}\right)\end{array}$ & $\begin{array}{c}\text { Tube } \\
\text { Dia. (mm) }\end{array}$ & $\begin{array}{c}\text { Pressure } \\
\text { (torr) }\end{array}$ & $\begin{array}{c}\text { Weight } \\
\text { Loss Rate }\left(\mathrm{R}_{\mathrm{m}}\right) \\
\left(\mathrm{gm} / \mathrm{cm}^{2} / \mathrm{min}\right) \\
\end{array}$ \\
\hline$V P-62 E$ & $S A C-60$ & 800 & 10 & $0.1(\mathrm{~A})$ & $6.8 \times 10^{-8}$ \\
\hline$V P-39 E$ & $S A C-61$ & 800 & 10 & $0.5(\mathrm{~A})$ & $1.9 \times 10^{-8}$ \\
\hline$V P-60 E$ & $S A C-60$ & 800 & 10 & 1 (A) & $7.3 \times 10^{-9}$ \\
\hline $\mathrm{VP}-40 \mathrm{E}$ & $S A C-61$ & 800 & 10 & $2.5(\mathrm{~A})$ & $4.5 \times 10^{-9}$ \\
\hline
\end{tabular}

\subsection{ISOTHERMAL CHEMICAL COMPATIBILITY}

The $700^{\circ}-800^{\circ} \mathrm{C}$ isothermal test series continues. The test conditions are summarized in Table VIII.

2.9 INGRADIENT COMPATIBILITY AND INGRADIENT LIFE TESTING

The performance of partitioned and non-partitioned P-legs which are on life test are summarized in Table IV.

\subsubsection{Non-Partitioned P-Legs}

The first seven tests in Table IV have been on test for approximately 61,400 hours. The performance has been quite stable during this period except for events such as power failures, instrumentation problems, etc. The data acquisition malfunction of November 1975 has been corrected and stable data are again being observed 
Top Summary Report No. 96

Page 18A

$$
\text { Figure } 1 .
$$

DEPENDENCE OF MEASURED WEIGHT LOSS

RATE ON INERT GAS PRESSURE

$$
T=800^{\circ} \mathrm{C}
$$

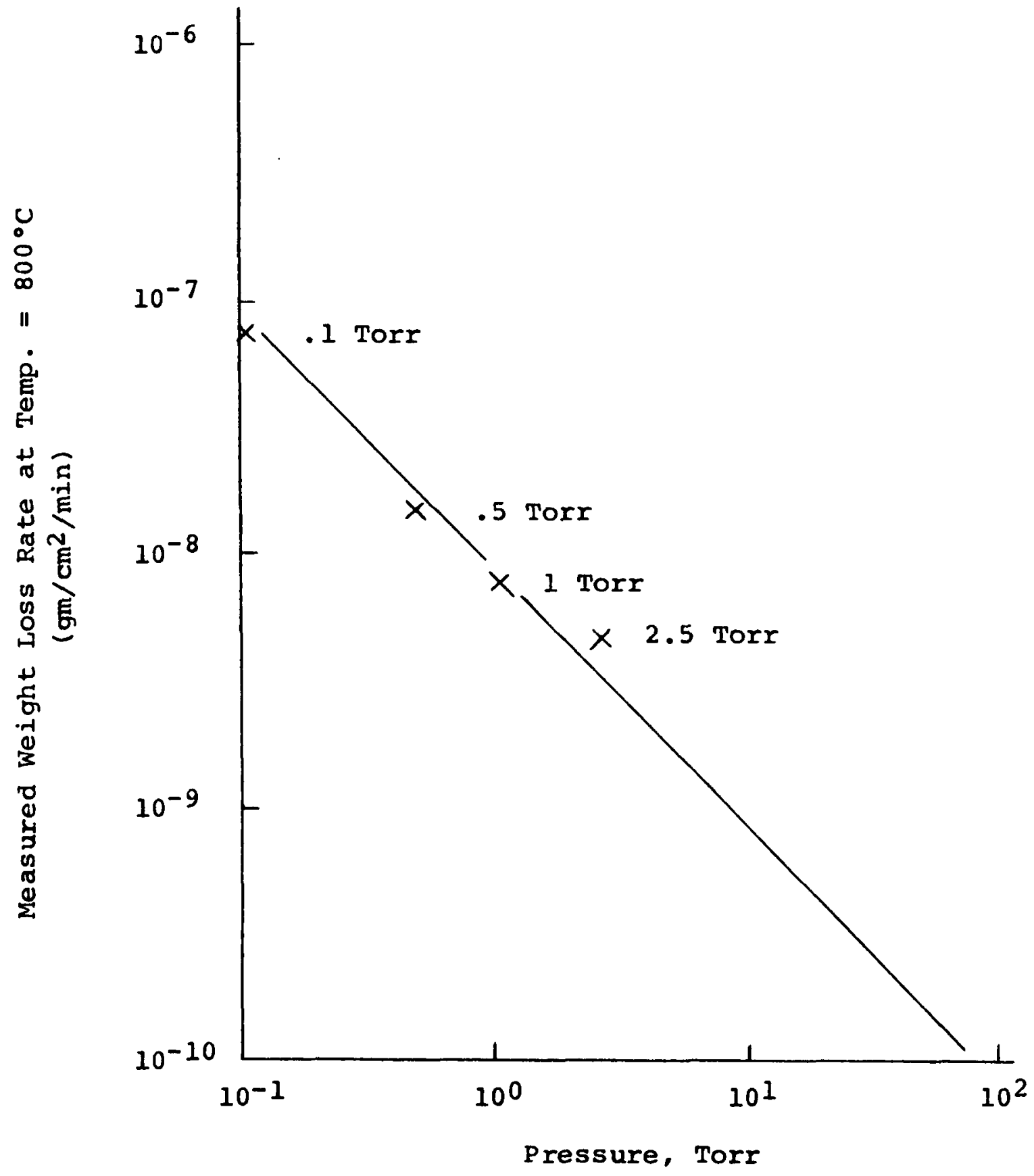


Top Summary Report No. 96

Page 19

TABLE VIII

P-Type TPM-217 Isothermal Chemical Compatibility

Test Description

I. Non-Magnetic Electrodes

A. $W$ and $W-25 R e$

B. Mo

II. Thermal Insulations
A. Fiberfrax $\left(\mathrm{Al}_{2} \mathrm{O}_{3} / \mathrm{SiO}_{2}\right)$
B. Fiberfrax $\mathrm{H}$ Blanket
C. Fiberfrax $660 \mathrm{H}$ HF Paper Insulation
D. $3 \mathrm{M} \mathrm{A} \mathrm{CO} 2$ Fiberfrax Insulation
E. Asbestos Fiber (component of Microtherm)
F. Min-K $2020\left(\mathrm{SiO}_{2} / 16 \mathrm{TiO}_{2}\right)$

Test Duration (Hrs)

$700-800$ $700-800$

33,370 and 30,570 respectively 33,370 and 30,570 respectively

III. System (Non-Magnetic Electrodes/Thermal Insulation)
A. W/Min-K 2020
B. W-25Re/Min-K 2020
C. W/Fiberfrax

$\begin{array}{lr}800 & 30,570 \\ 800 & 2,370 \\ 800 & 2,370 \\ 800 & 2,370 \\ 800 & 2,370 \\ 800 & 30,570\end{array}$

IV. Miscellaneous
A. $\mathrm{Cb}-103$ Rod
B. TZM Rod

800

V. Control TPM-217 
Top Summary Report No. 96

Page 20

for most tests. As reported last month, ATT 178 (an ingradient compatibility test with a molybdenum hot junction electrode in direct contact with TPM-217 at $700^{\circ} \mathrm{C}$ hot junction temperature) is continuing to exhibit erratic behavior. It is felt that this test should be examined in the near future. In general, the performance of the non-partitioned P-legs on life test continues to exhibit good stability.

\subsubsection{Partitioned P-Legs}

The partitioned P-leg tests are being monitored again this month after a data acquisition problem two months ago. Tests ATT 210, 241, and four tests in the six-station (ATT 371, 372, 373, 376) are performing well. Tests ATT 374 and 375 are producing spurious data which may be related to instrumentation problems.

Test PM-024:

Test PM-024 initiated in October, is being conducted in a test fixture equipped with a heat flux meter to provide information on the behavior of thermal conductivity with respect to time. The test element is a partition bonded P-TPM-217 element with the standard 0.3 -inch diameter by 0.3 -inch length geometry with a single partitioning foil 0.06 inch from the top. The operating conditions are $800^{\circ} / 200^{\circ} \mathrm{C}$ junction temperatures with 4.8 amp current.

This element is on test in the new 12-station fixture with radiantly heated hot end. The fixture is valved off from the main manifold turbo pump and is maintaining a pressure of $2 \times 10^{-7}$ torr at the ion pump. The principle objective of this test is to determine whether there exists any systematic change in thermal conductivity with time. Up to the present time, 3300 hours, no systematic change in $\bar{S}, \bar{p}$, or $\bar{K}$ has been observed; Figure 2 shows the deviations in $\bar{S}, \bar{\rho}$, and $\bar{K}$ from their initial values. This test will be continued.

\subsubsection{The 12-Station Test Fixture}

A problem was detected last month in the current control and measuring circuit of the 12-station test fixtures. The problem was caused by wiring the current control and measuring circuit to the ground side of the load current circuit which produced two sources of error--a ground loop error, and parallel paths error. This was corrected by rewiring the circuit. A description of the faulty circuit and its effects are given below to aid in preventing this and similar problems in the future. 
Deviation of Effective Seebeck Coefficient $(\bar{S})$, Resistivity $(\bar{\rho})$, and Thermal Conductivity $(\bar{k})$ from Their Initial Values

$s$ a Function of Test Time

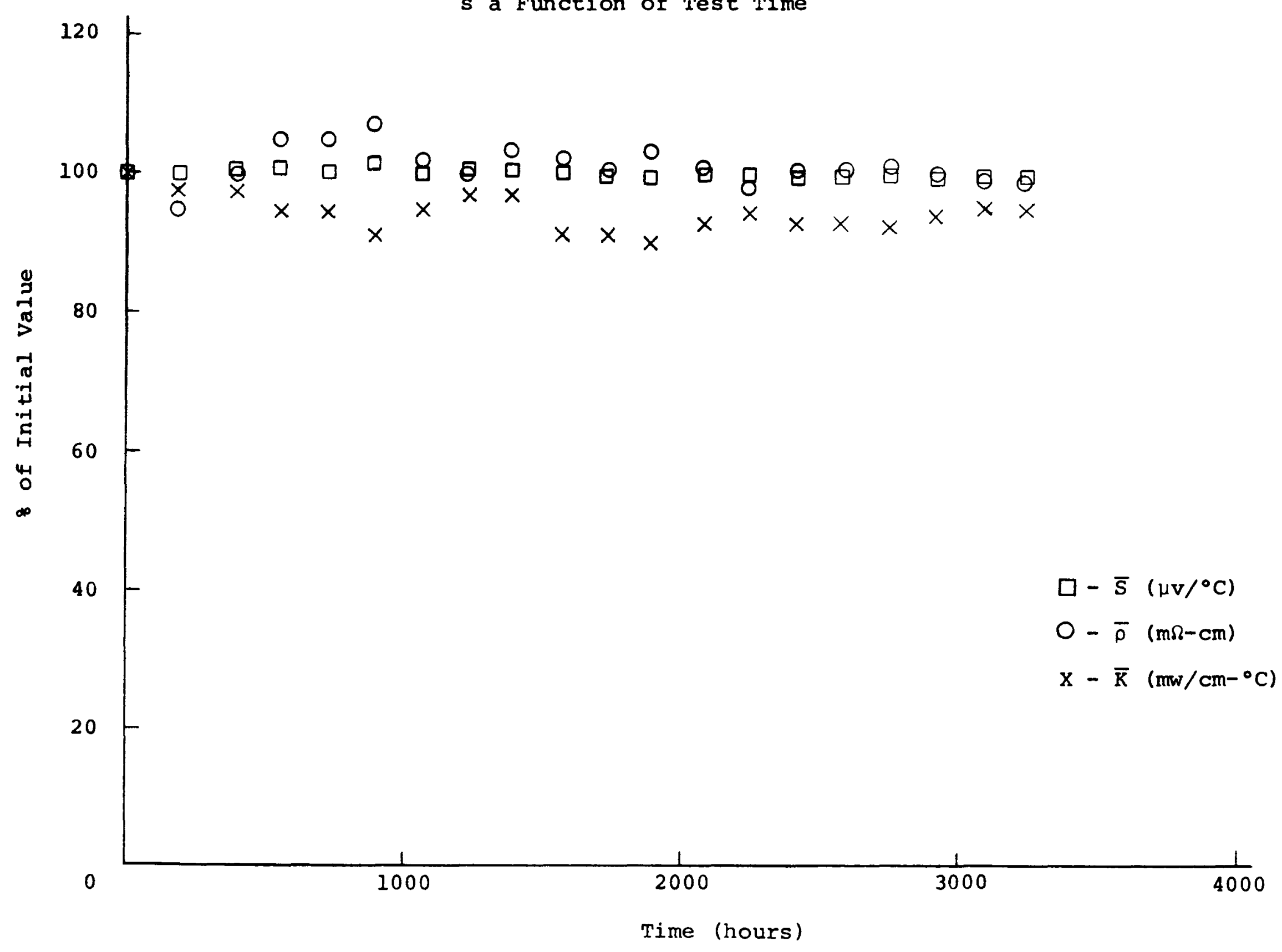


Top Summary Report No. 96

Page 22

The DC power supply had a finite resistance to ground which caused the ground loop. Since the cold end of all of the fixtures are connected to ground, a partially grounded power supply can cause currents to flow through the circuit which are not read by the series current shunt (Figure 3). The result of this extraneous current flow is that seebeck coefficient and resistivity readings are approximately 48 low.

The errors due to a parallel current path caused erroneous current readings both above and below the true readings. Figures 4 and 5 show the correct and problem circuits. The current control rheostats and the shunts were wired on the common ground side of the fixtures. The errors involved can be as much as $100 \%$ in the measured current.

The rewiring to correct these problems has been completed in eleven of the twelve fixtures. The twelveth fixture has milestone test PM-024. This fixture has the ground loop problem only because it is connected to a separated power supply. The problem will be corrected at the end of the test and appropriate corrections will be applied to the data. 
Fiqure 3. Ground Loop in Current Control and Measuring Circuit
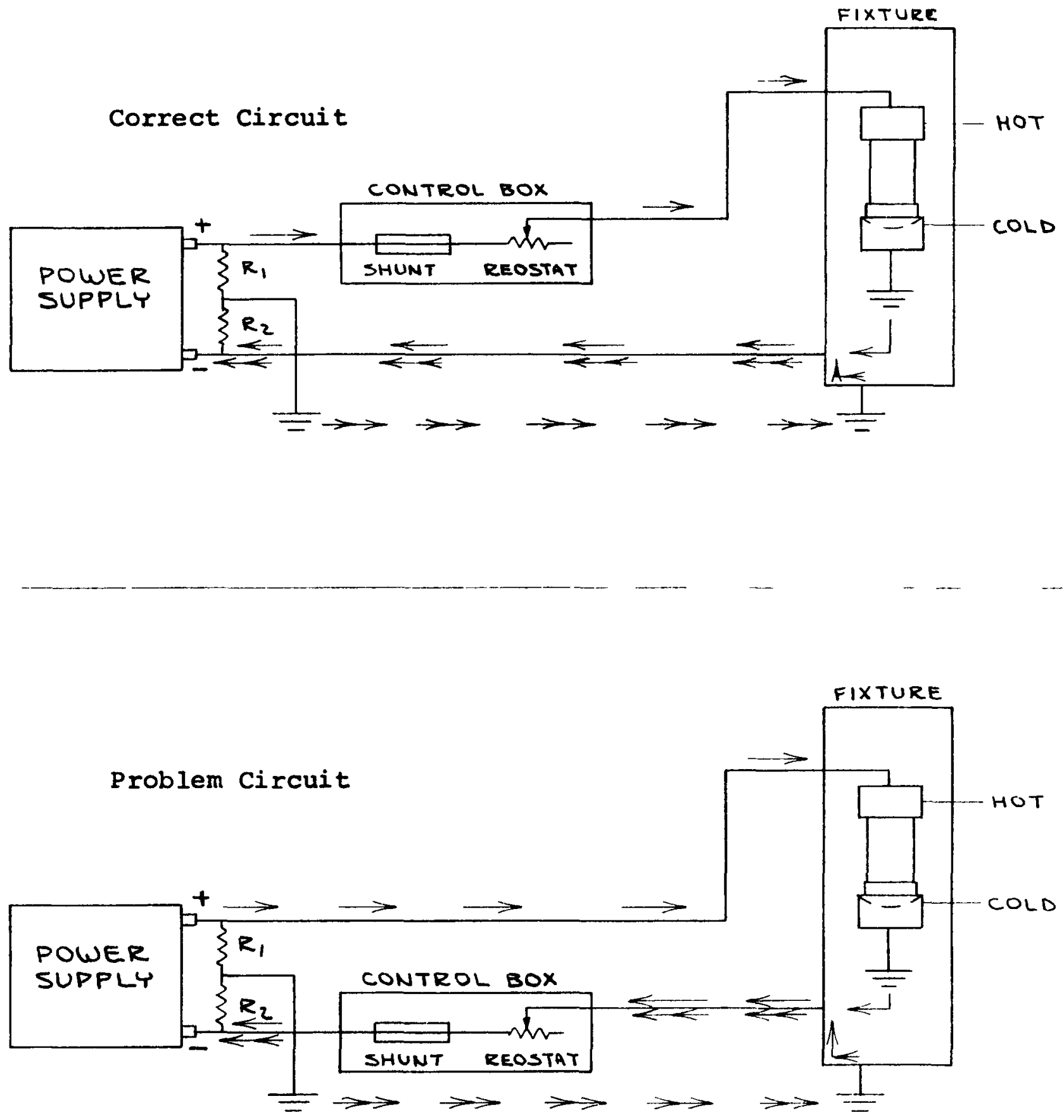

Normal Current path 
Figure 4. Corrent Current Control and Measuring Circuit when Test Fixtures are in Parallel

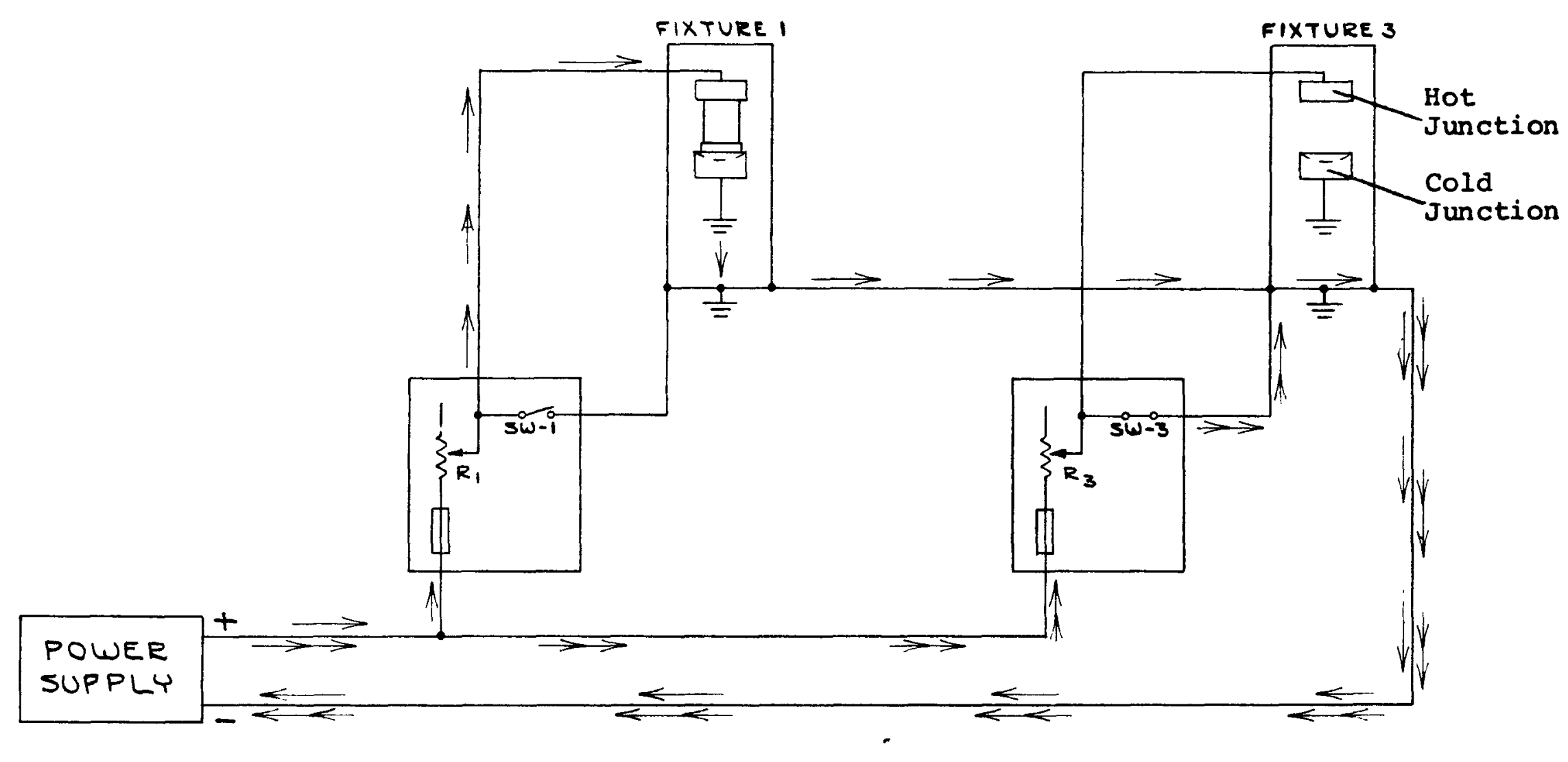

Current path for fixture \#l in operation

Current path for fixture \#3 not in operation 
Top Summary Report No. 96

Page 25

Figure 5. Problem Current Control and Measuring

Circuit when Test Fixtures are in

Parallel

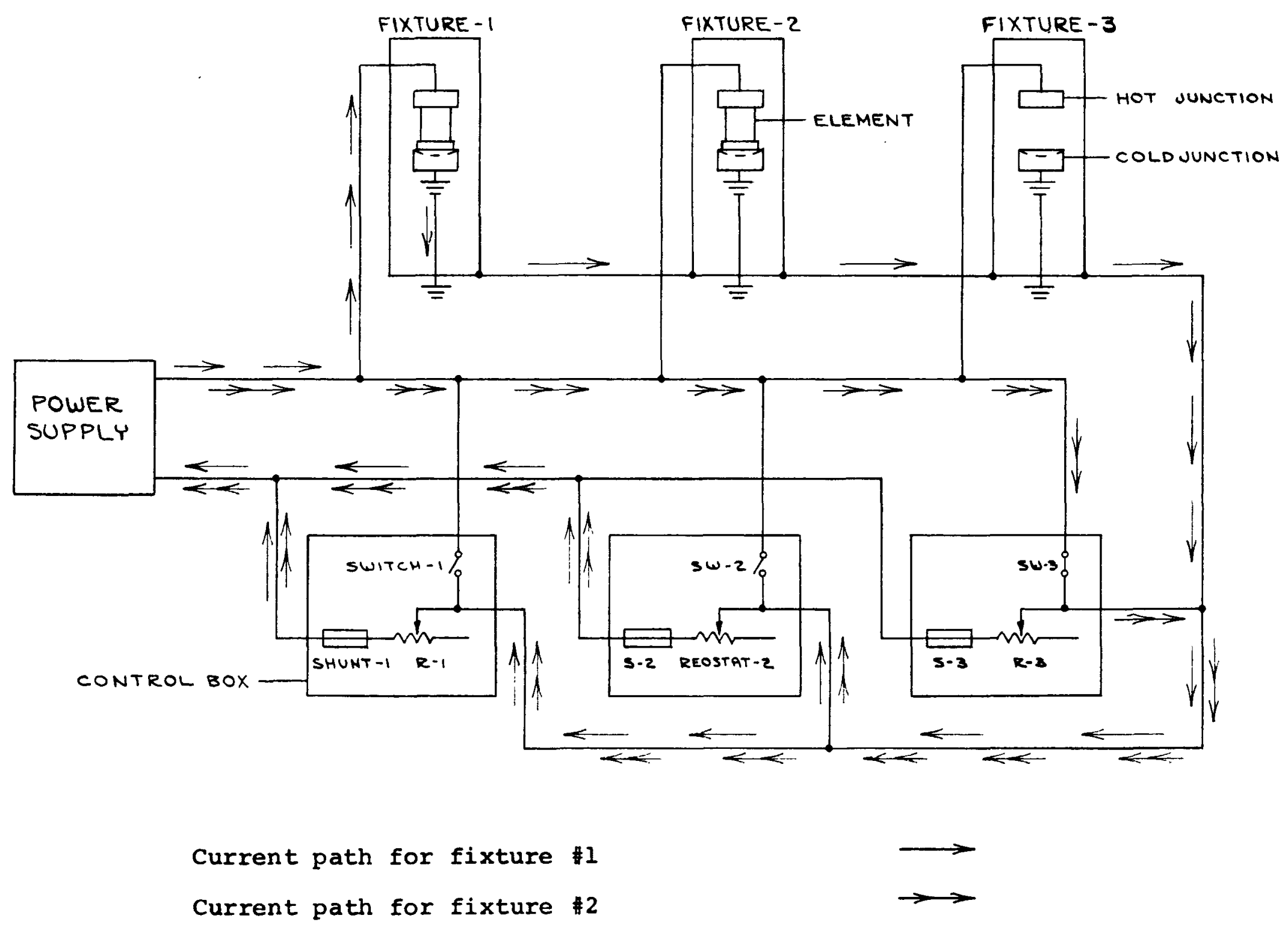


Top Summary Report No. 96

Page 26

\section{TASK 3.0 - COLPLE DEVELOPMENT}

\subsection{DESIGN AND DEVELOPMENT OF TPM-217/GADOLINIUM-SELENIDE RARE EARTH CHALCOGENIDE COUPLE}

The effort continues to utilize chemical, physical, and thermoelectric data which have been obtained on TPM-217 and gadoliniumselenide to develop effective couples appropriate to RTG operation.

Couple Test ATT 378/379:

A couple test (ATT 378/379) with hardware similar to that designed for the 20-watt module was placed on test to give an indication of the 20-watt module performance. This test has operated for 6200 hours in the temperature interval $800^{\circ} / 240^{\circ} \mathrm{C}$ in a vacuum of $4 \times 10^{-6}$ torr in the four-station facility.

This test has been cycled to room temperature four times. The first thermal cycle occurred at 30 hours when one of the chambers in the four-station facility developed a leak; the automatic shut-off circuit turned the station off. The test was exposed to a high pressure during cool down. Although the seat-in process was interrupted, the N-leg apparently did not crack because the resistance of the leg returned to the pre-thermal cycle values. The second thermal cycle at 350 hours was caused by a power failure in the building. The $\mathrm{N}$-leg apparently cracked because the resistance increased and was operating constantly at a higher value. The third temperature cycle apparently resulted in no further degradation because the properties returned to approximately the pre-thermal cycle values. The fourth thermal cycle apparently caused another degradation. Because of the numerous thermal cycles, the termination of this test is under consideration.

\subsection{DESIGN AND EVELOPMENT OF TPM-217/3N-PbTe COUPLES}

Couple test ATT 273 has now operated for 29,160 hours in the temperature interval $540^{\circ} / 140^{\circ} \mathrm{C}\left(1000^{\circ} / 285^{\circ} \mathrm{F}\right)$. The performance has remained the same as that previously reported.

Couple test ATT 275 was shut down at the time of the changeover to emergency power. This test has now been restarted and is at temperature. The power output is at approximately the same value as it was before the shutdown (Top Summary Report No. 81). The total operating time for this test is now 19,550 hours. 
Top Summary Report No. 96

Page 27

\subsection{ADVANCED GENERATOR CONCEPTS}

\section{HARDWARE DEVELOPMENT}

Follower Friction Testing:

The frictional force has been measured for a number of follower/ rail combinations. These measurements were obtained using the apparatus described in Top Summary Report No. 90 (pp. 27-28). A summary of the data is contained in Table IX. The designation, "rough or smooth" in the follower column indicates whether the part has been tested in the as-machined condition or whether a smoothing operating involving polishing stones has been employed. The designation " $\mathrm{Cr}-\mathrm{Cu} / \mathrm{Rh}(.0001)$ " refers to a chromium copper follower with a 0.0001 inch thick rhodium plate. The electroless nickel plate process is much harder but less pure than the sulfamate nickel plating process. The $\mathrm{MoS}_{2}$ is a molybdenum disulfide dry lubricant. This material was checked independently for outgassing and did not demonstrate any undesirable characteristics.

The force measurements provide a useful measure of the potential for a reduction of load pressure due to increased follower friction. These are short-term measurements, however, and long-term effects could exist and will be checked out. In addition, a visual inspection of the interfaces after testing provides another means of determining relative merit. In particular, it was observed that the rhodium plate had a tendency to scrape off the copper surface. To select a follower/rail combination, the heat transfer characteristics must also be evaluated. This has also been done for several candidate combinations and will be described later in this section.

The procedure in the friction force tests was to measure the net force on a follower while it was being moved inward and outward on a rail. The average of the maximum inward and outward values is reported in Table IX. These tests were performed in a vacuum of approximately $3 \times 10^{-6}$ torr and at a temperature of $200^{\circ} \mathrm{C}$.

A number of general conclusions drawn as a result of the friction force testing are:

1. The roughness of the mating surface has an influence on the observed frictional force (compare smooth ETP with rough ETP on a smooth 2024 aluminum rail).

2. With an electroless nickel rail, a rhodium plate on the followers reduced friction (this may not have been true on a long-term test because of the tendency of the rhodium plate to scrape off). 
FRICTIONAL FORCE MEASUREMENTS FOR VARIOUS RAIL/FOLLOWER COMBINATIONS

\begin{tabular}{|c|c|c|c|c|c|c|c|c|}
\hline \multirow[b]{2}{*}{$\begin{array}{l}\text { Test } \\
\text { No. }\end{array}$} & \multirow[b]{2}{*}{ Rail } & \multirow[b]{2}{*}{ Follower } & \multirow[b]{2}{*}{$\begin{array}{r}\text { Interface } \\
\text { Material } \\
\end{array}$} & \multicolumn{5}{|c|}{$\begin{array}{l}\text { Average Frictional Force for Motion } \\
\text { Inward and outward (1b) }\end{array}$} \\
\hline & & & & $\begin{array}{l}\text { Cycle } \\
\text { No. } 1\end{array}$ & $\begin{array}{l}\text { Cycle } \\
\text { No. } 2 \\
\end{array}$ & $\begin{array}{l}\text { Cycle } \\
\text { No. } 3 \\
\end{array}$ & $\begin{array}{l}\text { Cycle } \\
\text { No. } 4\end{array}$ & $\begin{array}{l}\text { Cycle } \\
\text { No. } 5 \\
\end{array}$ \\
\hline 1 & $\begin{array}{l}\text { Smooth } \\
2024 \mathrm{AI}\end{array}$ & $\begin{array}{l}\text { Smooth } \\
\text { ETP }\end{array}$ & None & 5.1 & 5.0 & 6.0 & 6.1 & 6.0 \\
\hline 2 & $"$ & Rough ETP & None & 6.9 & 6.6 & 8.1 & 8.8 & \\
\hline 3 & $"$ & $\begin{array}{l}\text { Smooth } \\
\text { ETP }\end{array}$ & None & 4.3 & 5.0 & 5.5 & 5.4 & \\
\hline 4 & $\begin{array}{l}\text { Electroless } \\
\text { Nickel }\end{array}$ & $\begin{array}{l}\mathrm{Cr}-\mathrm{Cu} \\
/ \mathrm{Rh}(.00002)\end{array}$ & None & 1.6 & 2.2 & 2.4 & & \\
\hline 5 & $"$ & $\begin{array}{l}\mathrm{Cr}-\mathrm{Cu} \\
\text { Smooth }\end{array}$ & None & 5.6 & 6.1 & 5.3 & & \\
\hline 6 & $"$ & $\begin{array}{l}\text { Smooth } \\
\text { ETP }\end{array}$ & None & 9.5 & 8.9 & 8.6 & & \\
\hline 7 & $"$ & $\begin{array}{l}\mathrm{Cr}-\mathrm{Cu} \\
/ \mathrm{Rh}(.0001)\end{array}$ & None & 1.2 & 1.3 & 1.4 & & \\
\hline 8 & " & $\begin{array}{l}\operatorname{ETP} \\
/ \operatorname{Rh}(.0001)\end{array}$ & None & 2.9 & 3.6 & 4.1 & & \\
\hline 9 & $"$ & $\begin{array}{l}\operatorname{ETP} \\
/ \operatorname{Rh}(.00002)\end{array}$ & None & 4.2 & 5.7 & 5.3 & & \\
\hline 10 & $\begin{array}{l}\text { Sulfamate } \\
\text { Nickel }\end{array}$ & $\begin{array}{l}\mathrm{Cr}=\mathrm{Cu} \\
/ \mathrm{Rh}(.0001)\end{array}$ & None & 2.8 & 1.7 & 1.8 & & \\
\hline 11 & $"$ & $\begin{array}{l}\operatorname{ETP} \\
/ \operatorname{Rh}(.0001)\end{array}$ & None & 4.3 & & & & \\
\hline 12 & $\begin{array}{l}\text { Electroless } \\
\text { Nickel }\end{array}$ & $\begin{array}{l}\mathrm{Cr}-\mathrm{Cu} \\
\text { Smooth }\end{array}$ & $\mathrm{MoS}_{2}$ & & & & & \\
\hline 13 & " & $"$ & $"$ & 1.1 & 1.4 & 0.8 & & \\
\hline
\end{tabular}


Top Summary Report No. 96

Page 29

3. With an electroless nickel rail, chromium copper followers exhibit less friction than ETP followers (compare test Nos. 5 and 6 ).

4. With a rhodium plated follower, electroless nickel had superior friction characteristics as compared to a sulfamate nickel plate.

5. The presence of the $\mathrm{MoS}_{2}$ interfacial material significantly reduces friction (compare tests 5 and 13).

Hardness Testing:

The hardness of follower and rail surfaces has been shown to have an influence on the frictional characteristics of rail/follower interfaces. The hardness of various test materials has been measured and the results are summarized in Table $\mathrm{X}$.

Some of the measurements were made using the Rockwell G test and others using the Rockwell $\mathrm{k}$ test. They were all converted to Brinnell harness number. This conversion process is usually quite unreliable, so comparisions between $R_{G}$ values and $R_{K}$ values should be made only with great caution. Some general observations may, however, be made:

1. Operation at $200^{\circ} \mathrm{C}$ softens $2024 \mathrm{Al}$ and ETP copper.

2. Rh plating on copper decreases the hardness of the part.

3. $\mathrm{Cr}-\mathrm{Cu}$ is harder than ETP copper.

Additional measurements will be performed on similar parts in the future. An attempt will be made to perform all tests with the same Rockwell test to eliminate hardness number conversion problems.

Follower/Rail Thermal Resistance Testing:

There is a trade-off between low friction and low thermal resistance for the sliding follower/rail surfaces. That is, the physical properties which produce low friction tend to produce high thermal resistance and vice versa. Hardness is a typical example. Thus, it is necessary to compare both friction and thermal resistance for candidate interfaces to obtain the optimum pair. A three-couple module was assembled in the hardware motion fixture and the thermal resistance of the follower/rail interface was measured for various types of interfacial materials. These results are summarized in Table XI. An electroless nickel rail and three $\mathrm{Cr}-\mathrm{Cu}$ followers were used. The interfacial material varied. 
Top Summary Report No. 96

Page 30

TABLE $X$

Hardness of Various Module Materials

Material

2024 Al Rail

(before testing

at $200^{\circ} \mathrm{C}$ )

2024 Al Rail

(after testing)

ETP Follower

(before testing)

ETP Follower

(after testing)

Electroless Nickel

Plated Rail

Sulfamate

Plated Rail

ETP Follower

(.0000" Rh Plate)

ETP Follower

(.0001" Rh Plate)

Cr-Cu Follower

(.00002" Rh Plate)

$\mathrm{Cr}-\mathrm{Cu}$ Follower

(.0001" Rh Plate)
Measured Hardness

$47 \mathrm{R}_{\mathrm{G}}$

$41 \mathrm{R}_{\mathrm{G}}$

$62 R_{G}$

$58 \mathrm{R}_{\mathrm{G}}$

$46 \mathrm{R}_{\mathrm{G}}$

$46 \mathrm{R}_{\mathrm{G}}$

$63 \mathrm{R}_{\mathrm{K}}$

$45 \mathrm{R}_{\mathrm{K}}$

$91 \mathrm{R}_{\mathrm{K}}$

$93 \mathrm{R}_{\mathrm{K}}$
Hardness (BHN)

148

138

178

168

145

145

82

66

160 
Top Summary Report No. 96

Page 31

TABLE XI

Follower/Rail Thermal Resistance

\begin{tabular}{lcc} 
Follower & $\begin{array}{c}\text { Interface } \\
\text { Material }\end{array}$ & $\begin{array}{c}\text { Resistance } \\
\left({ }^{\circ} \mathrm{C} / \mathrm{w}\right)\end{array}$ \\
\cline { 2 - 3 } N-Leg & None & 1.8 \\
P-Leg & None & 8.1 \\
N-Leg & MoS $_{2}$ & 10.5 \\
P-Leg & Mos $_{2}$ & 35.0 \\
N-Leg & Mose $_{2}$ & 13.5 \\
P-Leg & Mose & 10.4
\end{tabular}

The MoS $_{2}$ material is a commercial produced called Molykote $\mathrm{z}$ powder. The MoSe $_{2}$ material was synthesized in our laboratory. The general conclusions are that the interfacial coating appears to severely degrade the heat transfer characteristics of the interface, esepcially in the case of the MoS $_{2}$. There is scatter in the data, so additional testing will ultimately be performed to verify these conclusions.

Cold End Current Strap Attachment:

The attachment of the cold junction current strap is the final assembly step for the bonded and partitioned p-elements. In the past, there has been a failure rate of about $10 \%$ in this assembly operation, the mode of failure being a separation of the leg below the partition. Previously, legs that went through this process were not tested ingradient because the test seemed to weaken the partition bonds.

A series of elements were tested to determine if legs that were tested by the standard $Q C$ procedure would have a different failure rate. The legs used passed all QC inspection. The only property that could affect the ability to complete a good staking assembly would be the electrical resistivity; a high value could indicate a poor bond. Therefore, the test series should identify a worst case failure rate.

Twenty-one elements had the current strap staked in place; the failure rate and mode of failure was the same as before, $10 \%$ rate, and separation of the leg below the partition. Some possible causes of the separation are poor bond strength and/or the staking methods. 
Top Summary Report No. 96

Page 32

The staking tool was examined to determine its ability to accommodate all partitioned and bonded p-elements which pass the quality control acceptance limits. The acceptable limits of various dimensions which play a part in this examination are listed below:

1. The bonding surface of the copper electrode -0.339 to 0.346 inch diameter.

2. The element must be centered a minimum of 0.008 inch from the edge of the copper electrode.

3. The diameter of the element -0.290 to 0.295 inch.

4. The diameter of the $\mathrm{W} / \mathrm{Re}$ partitioning foil is 0.320 inch it must extend a minimum of 0.005 inch out from the element.

5. The diameter of the staking tool is 0.330 inch at the staking point, and 0.375 inch diameter in the body.

A worst case condition was assumed; that is, all the dimensions at the limit that could cause a problem. This condition is shown in Figure 6. There are two points of concern--where the staking tool contacts the copper electrode, and where the staking tool body may contact the partition foil (Figure $6, A$ and $B$ ). With the present dimensional limits, there is a possibility that there would be zero clearance between the staking tool and the element on the copper electrode (point $A$ ). The dimensions of the two elements that failed were checked, and this was not the case. To prevent this from ever occurring, the specifications for the maximum diameter of the copper electrode should be changed from 0.346 inch to 0.345 inch, and the minimum centering of the element on the copper electrode should be changed from 0.008 to 0.010 inch. Neither of these changes in specifications would have rejected a leg or copper electrode to date.

The second point of concern, the staking tool body and partition foil (Figure 6 , point B), potentially could have overlapped by 0.002 inch. Again, this was not the case with the two legs that failed. To prevent this from ever occurring, the body of the staking tool will be enlarged to 0.400 inch diameter. This, and the change in dimensional specifications recommended above, will yield a minimum gap of 15 mils at point $B$.

The dimensional aspects of the staking method are probably not the cause of the present failure rate but, by making the changes noted, it should prevent any future problems. 
Top Summary Report No. 96

Page 33

Figure 6. Worst Case Conditions for a P-Element in the staking Process

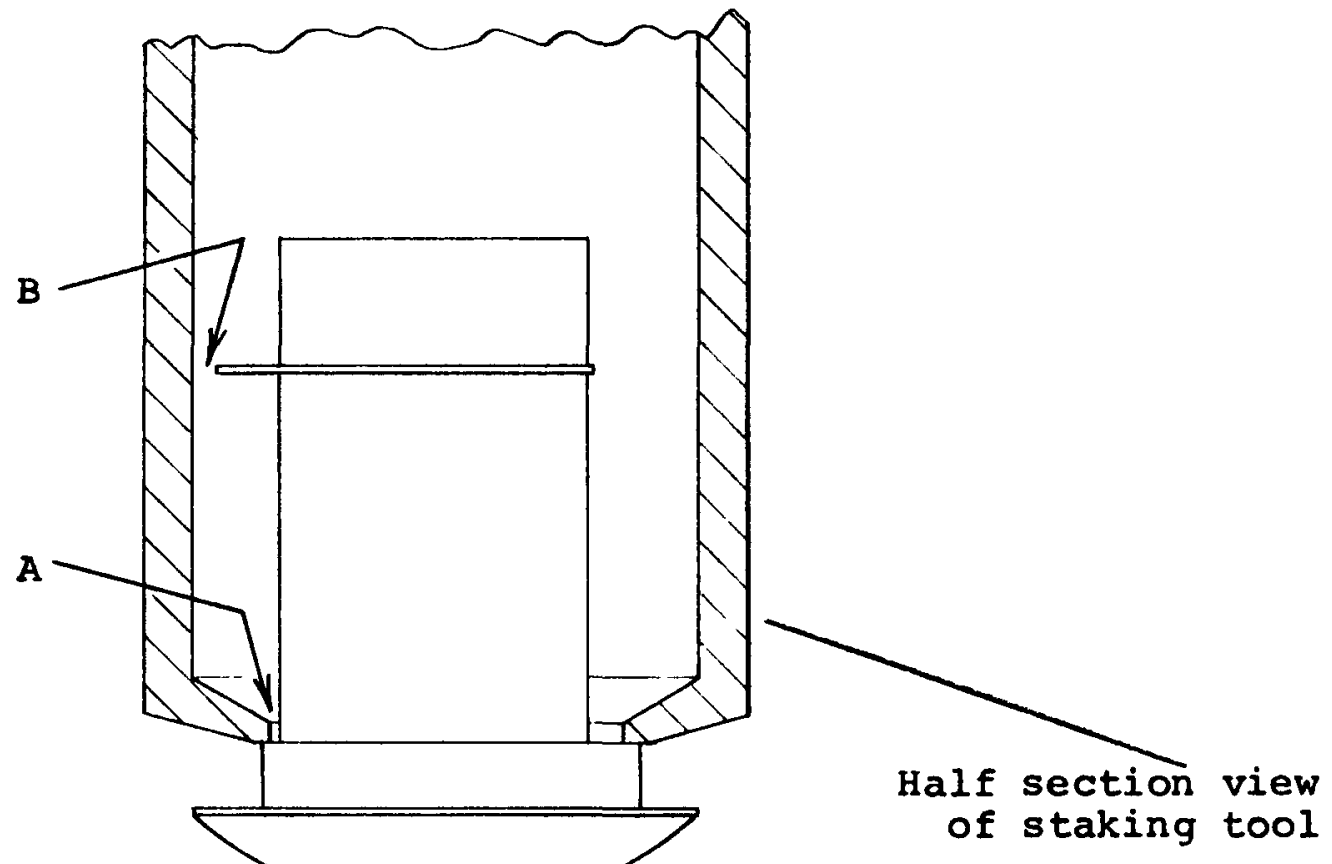

$A$ and $B$ are potential problem points 
Top Summary Report No. 96

Page 34

\section{Task 4.0 - Module Development}

\section{MODULE M-1 - TWO-COUPLE MODULE:}

The two-couple module, $\mathrm{M}-1$, has completed 14,200 hours of operaation in a temperature interval $800^{\circ} / 200^{\circ} \mathrm{C}$ and a vacuum of about $10^{-4}$ torr. A power interruption at 3500 hours produced a temperature cycle which caused an irreversible change of performance. This temperature cycle undoubtedly resulted in cracked $\mathrm{N}-$ legs which was indicated by an increased resistance at that time. The cold junction of the module cycled to about $120^{\circ} \mathrm{C}$ at 4850 hours. This cycle had little effect on the average seebeck coefficient of the $\mathrm{N}$ - and $\mathrm{P}-\mathrm{legs}$ or on the resistance of the $\mathrm{N}-$ legs. The average resistance of the two P-legs increased by about 48 and has remained stable until this month. During the last month, the resistance of the P-leg increased by about a factor of three, indicating a contacting problem. Thus, high resistance produces a decrease in power output (Figure 7). This behavior is indicative of reduced load pressure and is somewhat similar to the problems observed on $M-5$. The followers used on $\mathrm{M}-1$ have long since been replaced so that the solution to this problem is being obtained by the current follower friction studies.

\section{MODULE M-5 - 10-COUPLE MODULE:}

Module $M-5$ has been operating in a vacuum of $7 \times 10^{-8}$ torr and a temperature interval of $800^{\circ} / 200^{\circ} \mathrm{C}$ for 5100 hours. The thermoelectric performance from the time that the $800^{\circ} / 200^{\circ} \mathrm{C}$ temperature was attained is displayed in Figures 8 through 16 . The performance increased initially as seat-in occurred, but remained relatively stable from approximately 150 hours to 750 hours. At 750 hours the temperatures were adjusted to bring them more in line with the nominal values of $800^{\circ} / 200^{\circ} \mathrm{C}$. The power output subsequently increased from 4.2 to 4.4 watts. At approximately 1000 hours the resistance of one of the $\mathrm{N}$-legs discontinuously increased from 22 to 60 milliohms (Figure 15). This did not occur at the same time as the temperature adjustment. Any temperature change which would have occurred at this time would have been minor.

This N-leg resistance has been gradually decreasing since the time of the discontinuous change and was approximately 24 milliohms at the end of the month. Thus, it appears that this $\mathrm{N}-1$ eg is undergoing the same type of behavior exhibited by the two Nlegs during the first 1000 hours of operation (Top Summary Report No. 90). That is, the change may have been caused by a slight end cracking which ultimately improves with seat-in, or a slight hang-up on the follower which finally freed itself. Two other Nlegs have also exhibited some increase in resistance this month. Due to the erratic nature of the resistance variation, it appears that these changes may be due to contacting and follower hang-up. 
Top Summary Report No. 96

Page 35

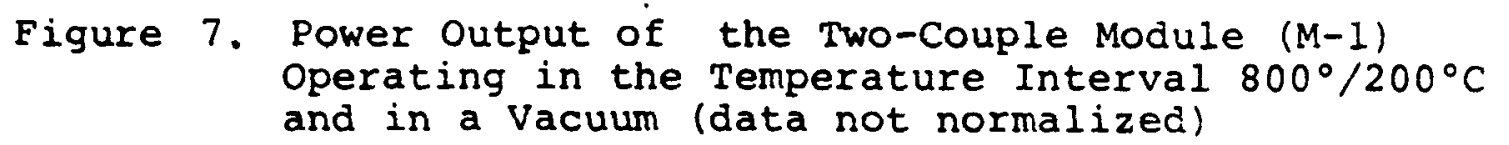
and in a Vacuum (data not normalized)

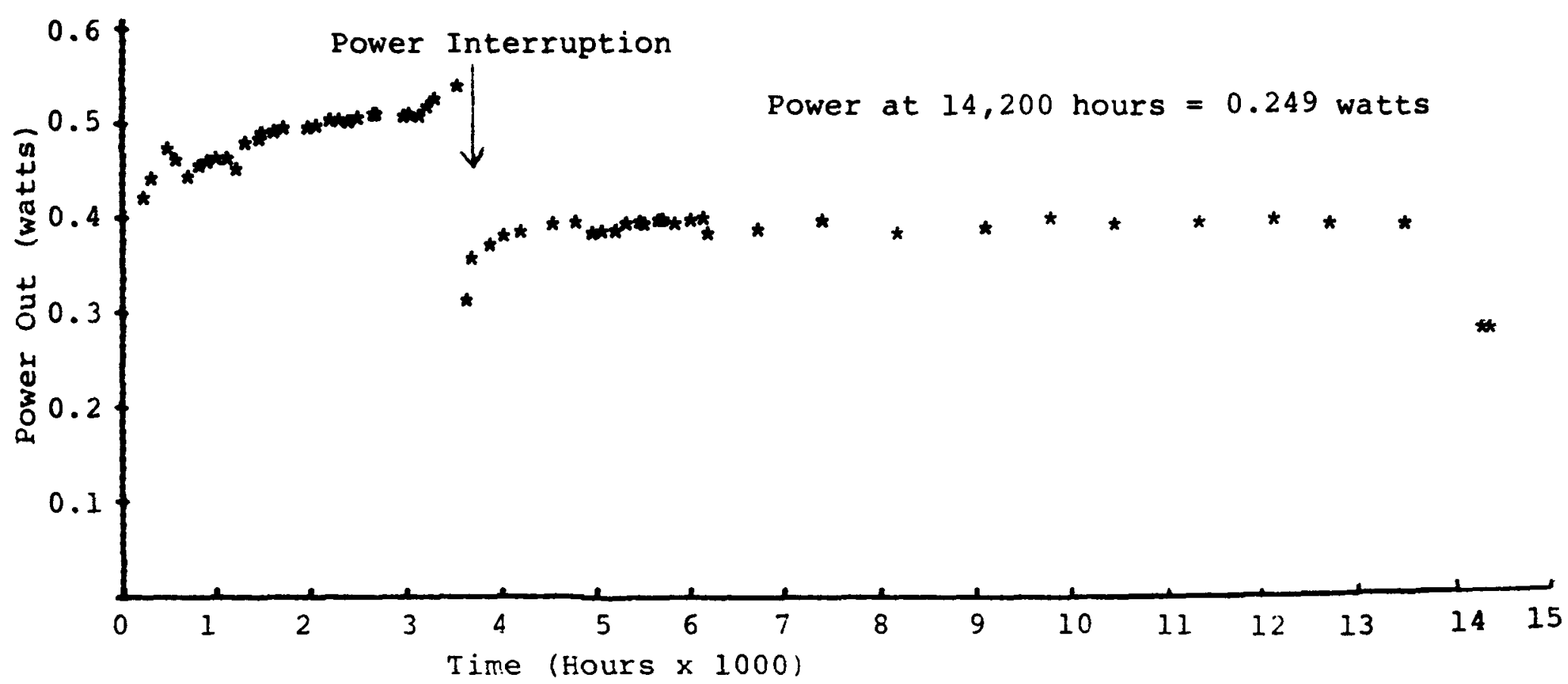


Top Summary Report No. 96

Page 36
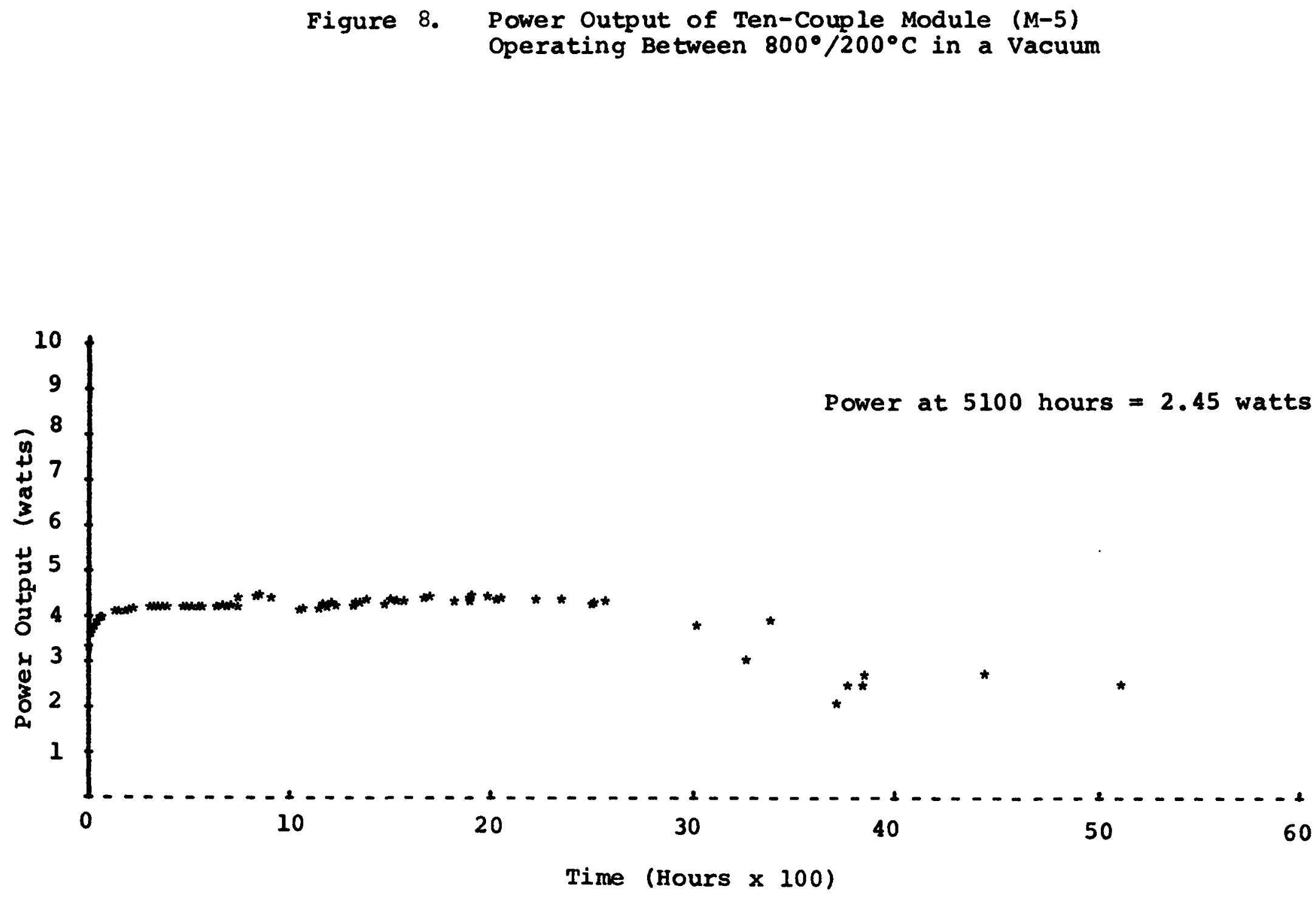
Top Summary Report No. 96

Page 37
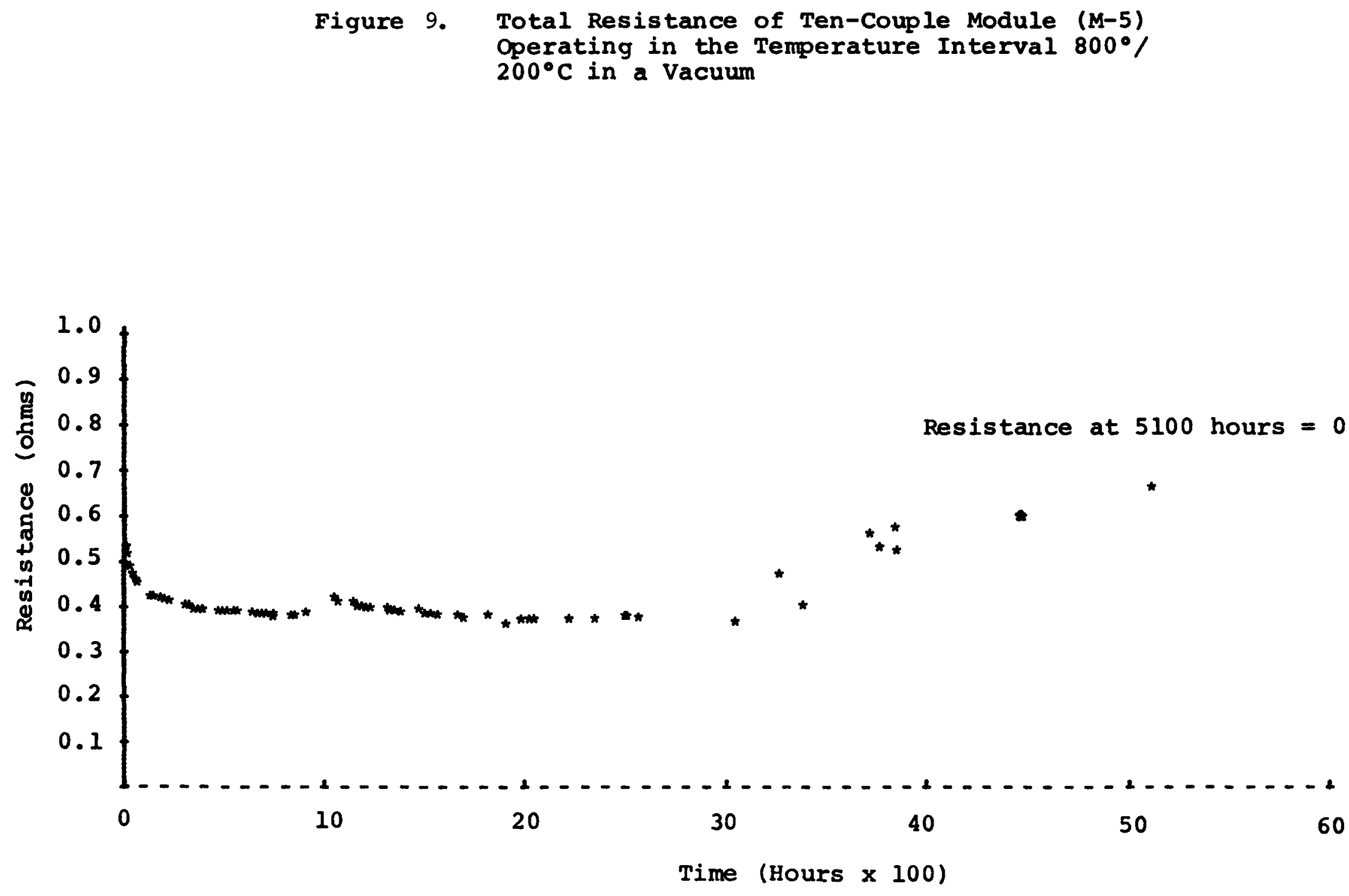
T'op Summary Report No. 96

Page 38

Figure 10. Open-Circuit Voltage of Ten-Couple Module (M-5) Operating Between $800^{\circ} / 200^{\circ} \mathrm{C}$ in Vacuum

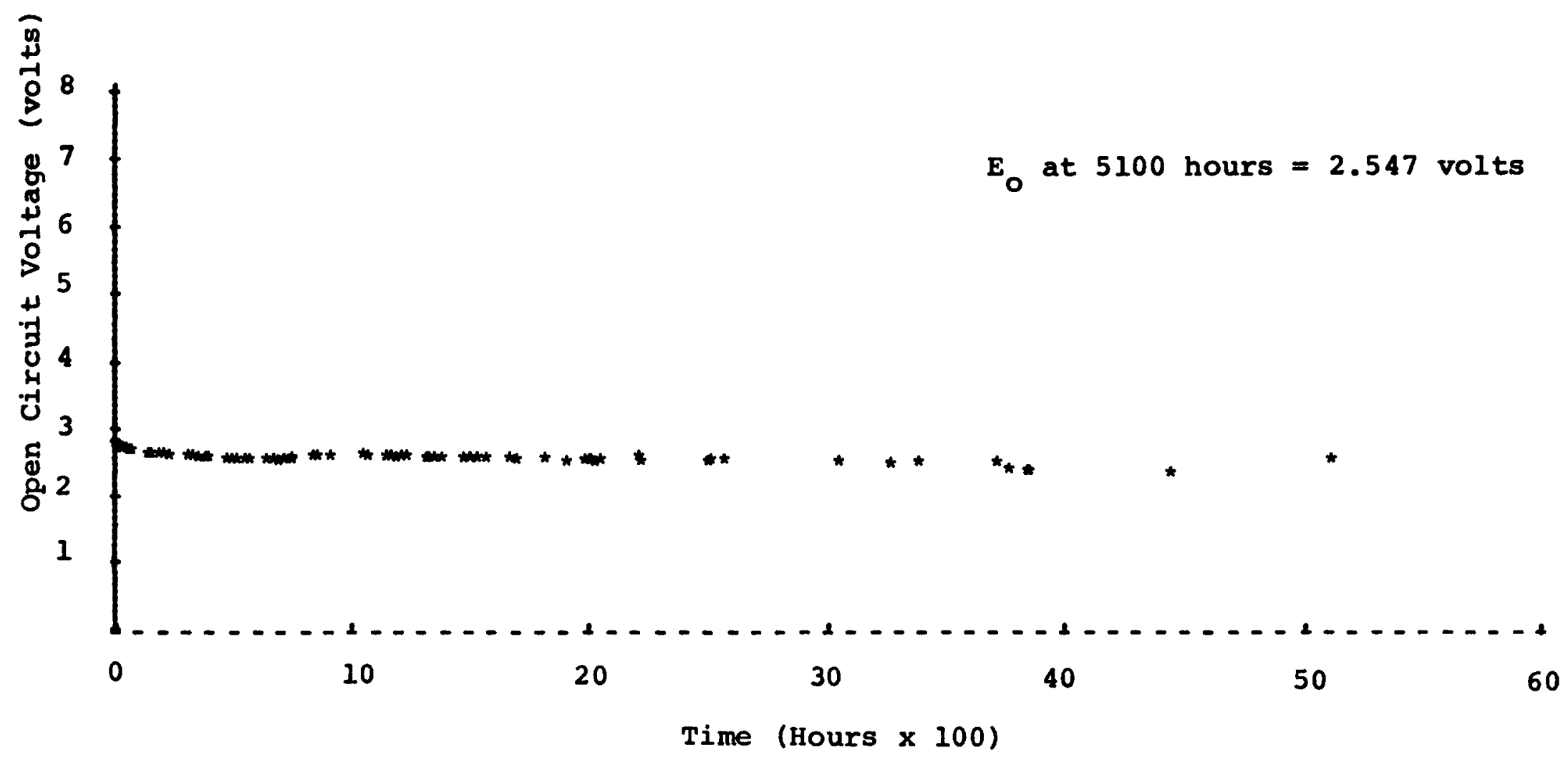


Top Summary Report No. 96 Page 39

Figure 11. Average Hot End Temperature of Ten-Couple Module (M-5) with Nominal Temperature Interval of $800 \%$ $200^{\circ} \mathrm{C}$ in a Vacuum

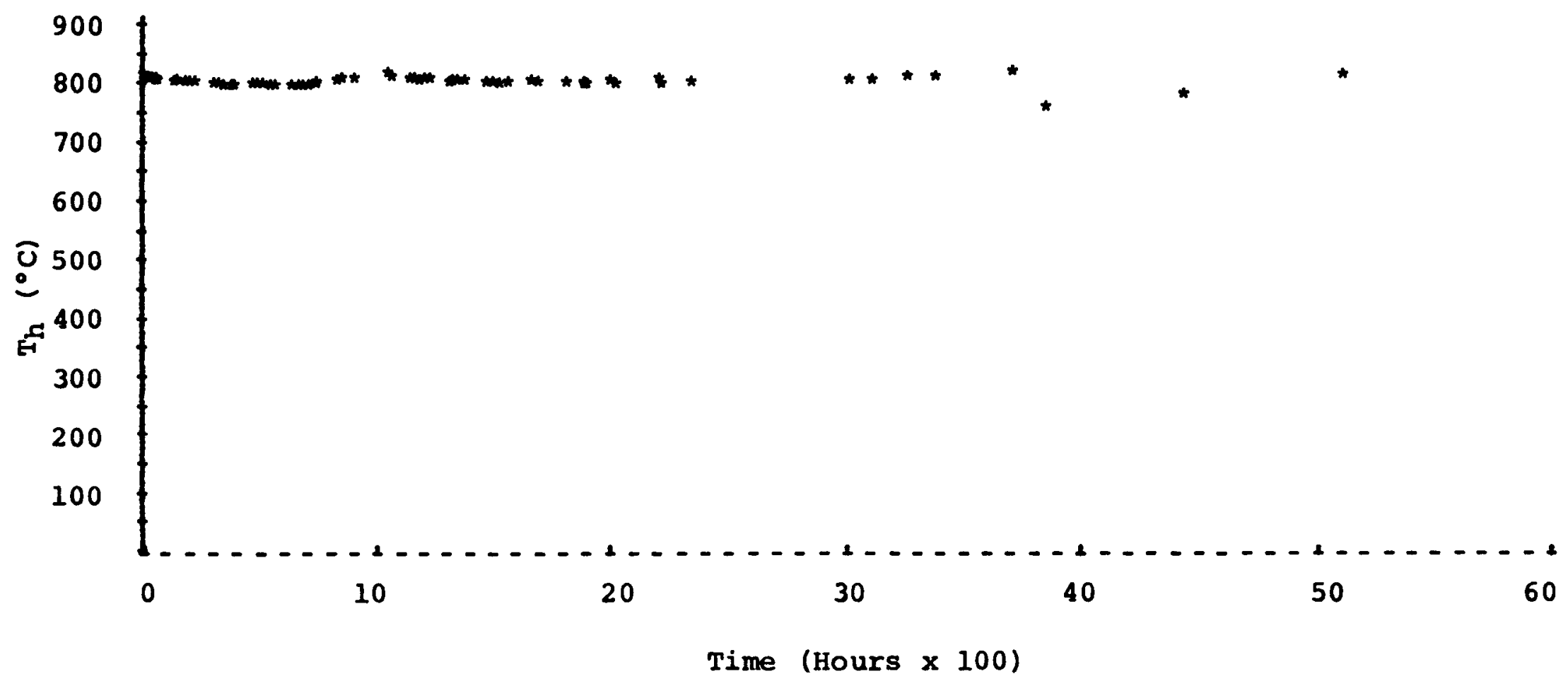


Top Summary Report No. 96 Page 40

\section{Figure 12. Average Cold End Temperature of Ten-Couple Module (M-5) with Nominal Temperature Interval of $800 \%$ $200^{\circ} \mathrm{C}$ in a Vacuum}

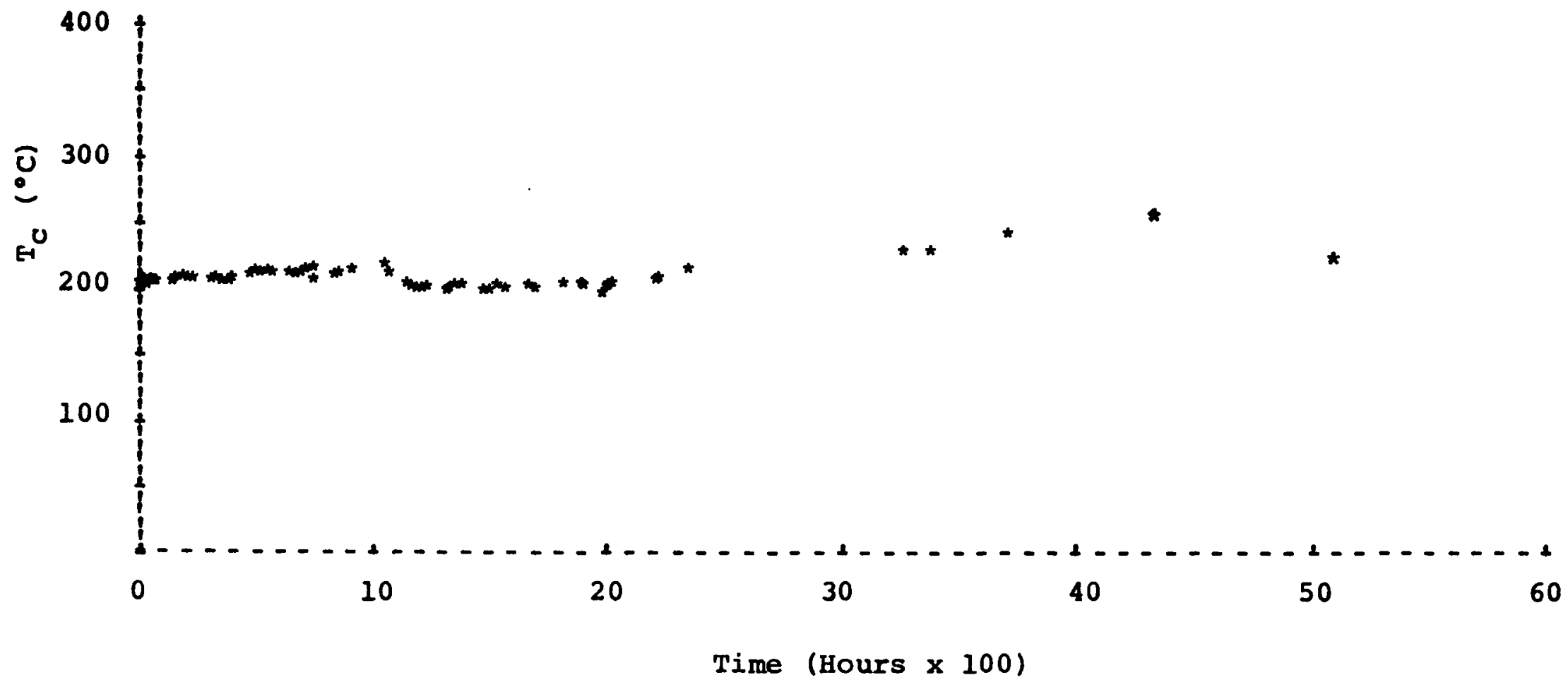


Figure 13. Ingradient Seebeck coefficient of TPM-217 N-Legs in Ten-Couple Module $(M-5)$ Operating in the Temperature Interval $800^{\circ} / 200^{\circ} \mathrm{C}$ in a Vacuum

足

O

苑.

邑 200

总

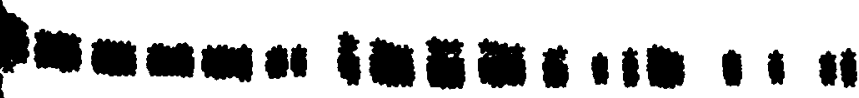

\section{$1 !$}

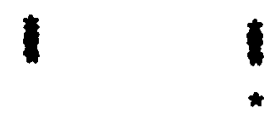


Top Summary Report No. 96

Page 42

Figure 14. Ingradient Seebeck Coefficient of P-Legs in Ten-Couple Module $(M+5)$ Operating in the Temperature Interval $800 \%$ $200^{\circ} \mathrm{C}$ in a vacuum

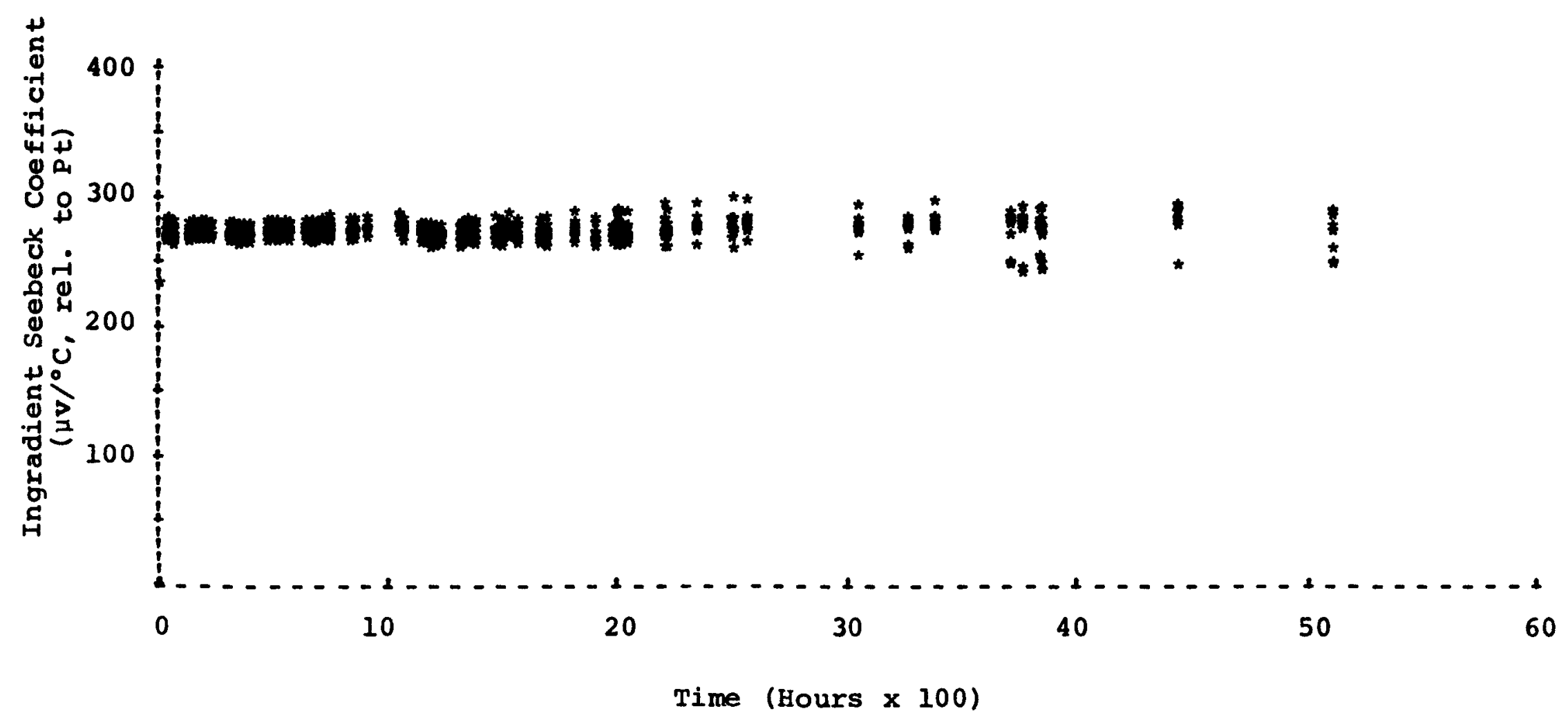


Top Summary Report No. 96

Page 43

Figure 15. Resistance of $\mathrm{N}$-Legs in Ten-Couple Module $(\mathrm{M}-5)$
Operating in the Temperature Interval $800 \% 200^{\circ} \mathrm{C}$ in a Vacuum

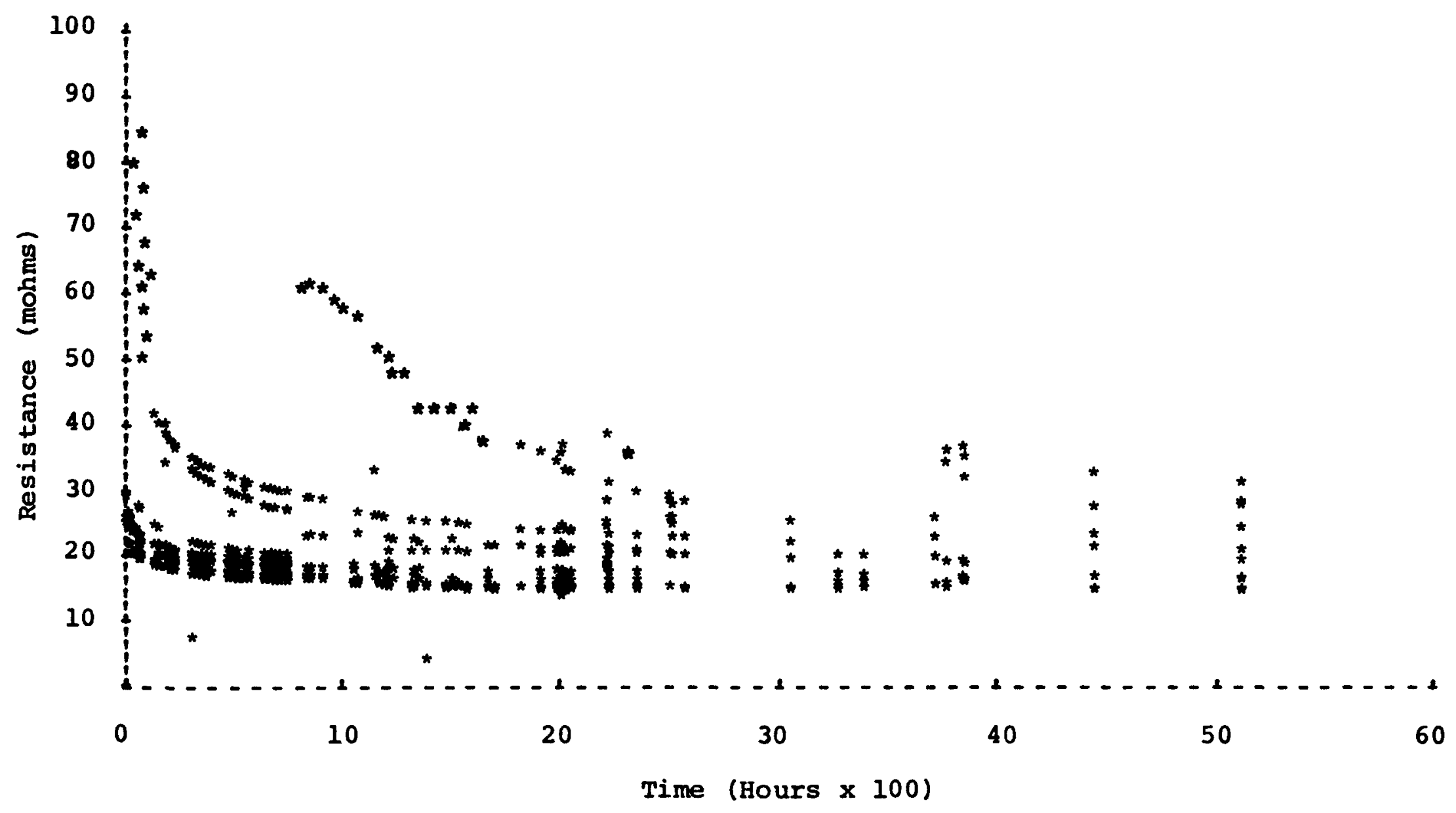


Top Summary Report No. 96

Page 44
Figure 16. Resistance of P-Legs in Ten-Couple Module (M-5) Operating in the Temperature Interval $800^{\circ} / 200^{\circ} \mathrm{C}$ in a Vacuum
- (248)

$\star(245)$

$$
\begin{gathered}
(163) * \\
(115) *(69) \quad *(93) *(94) \\
*(52)
\end{gathered}
$$


Top Summary Report No. 96

Page 45

The resistances and seebeck coefficients of the remainder of the $\mathrm{N}$-legs are uniform (Figures 13-15). In addition to plots of the power, Seebeck coefficient, and resistance, the open circuit voltage and temperature history of $\mathrm{M}-5$ are plotted in Figures 10,11 , and 12 .

The power output of the M-5 which had degraded during December 1975 (Figure 8), primarily as a result of the increase in resistance of two P-legs, (Figures 9 and 16) has now stabilized. The value of resistances greater than 50 milliohms is shown in parentheses. The P-leg resistance of these legs is erratic, which is indicative of an electrical contacting problem. This behavior is probably caused by a reduction in load pressure on the P-legs. Resistance values have varied between 20 and 250 mohms for one leg. These variations have been random. The $P$-leg followers have weaker springs than the N-leg followers; thus, they have less ability to counteract friction between the follower and the rail. Current investigations in the follower/rail friction apparatus will define this problem more completely, and a solution to this problem will be identified as a result of these studies. A variety of materials, coatings, and surface preparations are being evaluated to determine the optimum rail/follower combination.

MODULE M-6 - TEN-COUPLE MODULE :

Module M-6 will be a ten-couple module similar in configuration to $M-5$. The changes in $M-6$ are summarized below:

$\frac{\text { Module }}{\text { Rail }} \quad \frac{M-5}{2024 \text { Al }}$

Follower

Rail/Follower

Interface Material

Hot End Gimbal

N-Legs
ETP Copper

None

Standard

1008 Extraneous

Resistance
$\underline{M-6}$

2024 Al with

Electroless Nickel Plate

Chromium-Copper

None

Improved

50\% Extraneous Resistance

The selection of the rail/follower configuration is somewhat tentative based on the results of a longer-term friction test which has just been started. If the frictional characteristics remain good with time, the configuration described above will be used. 
Top Summary Report No. 96

Page 46

\section{Task 9.0 - Program Management}

Work under this task included technical direction and overall coordination of activities associated with the program and liaison with ERDA. The following report was published during this period:

Top Summary Report No. 95, dated February 9, 1976

Messrs. W. Barnett, A. Lieberman, and W. Osmeyer of Teledyne Isotopes, and Mr. A. Schafffauser of ORNL visited $3 M$ on February 5 , 1976, to discuss chemical compatibility related to the LCHPG program. A program review was held at ERDA/DANES on February 12, 1976, with Messrs. E. Hampl and R. Reylek in attendance. 